\title{
TRAINING
}

\section{SAMEN WERKEN AAN HET BIJENLANDSCHAP}

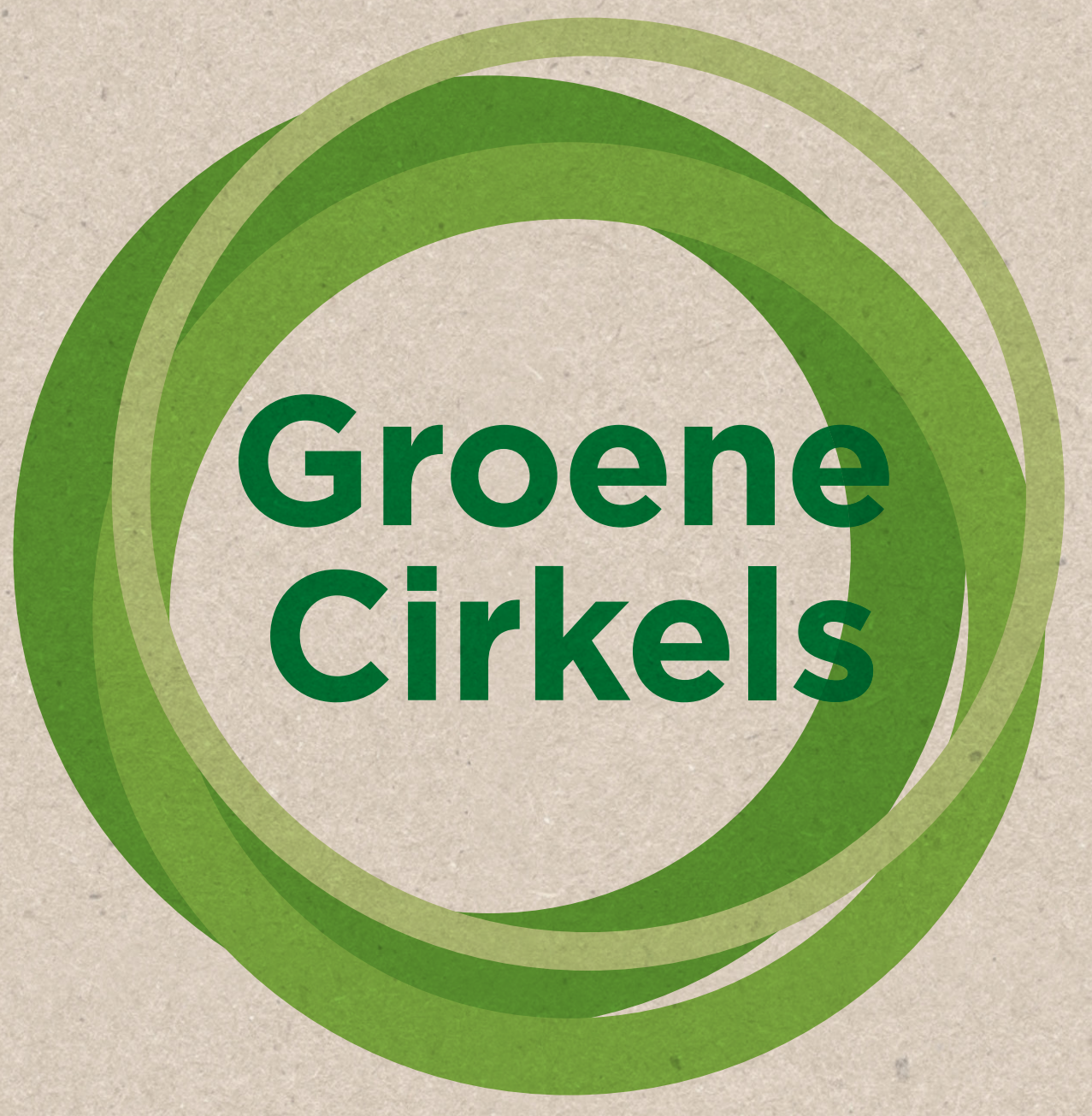




\section{COPYRIGHT}

(c) Groene Cirkels

Dit rapport is gratis te downloaden van https://doi.org/10.18174/520308.

U mag deze training gebruiken onder de volgende voorwaarden:

Naamsvermelding - De gebruiker dient de maker van het werk te vermelden, een link naar de licentie te plaatsen en aan te geven of het werk veranderd is. $U$ mag dat op redelijke wijze doen, maar niet zodanig dat de indruk gewekt wordt dat de licentiegever instemt met uw werk of uw gebruik van het werk.

Niet commercieel - U mag het werk niet gebruiken voor commerciële doeleinden.

Geen afgeleide werken $-U$ mag het veranderde materiaal niet verspreiden als $u$ het werk hebt geremixt, veranderd, of op het werk hebt voortgebouwd.

Wij stellen het op prijs als u ons inlicht over uw gebruik van de training. Neem ook even contact op als $u$ de training op een andere wijze dan hierboven genoemd wilt gebruiken. Meerinformatie: francine.loos@wur.nl 


\section{Groene Cirkels}

Een Klimaatneutrale HEINEKEN brouwerij, een duurzame economie én een aangename leefomgeving in de regio Zoeterwoude. Dat zijn de ambities waarvoor Groene Cirkels zich inzet. Dat doen zij door de natuur als uitgangspunt te nemen en programma's te realiseren rond de onderwerpen energie, water, grondstoffen, mobiliteit en leefomgeving. Het initiatief Groene Cirkels, gevormd door multinational HEINEKEN, provincie ZuidHolland, het Hoogheemraadschap van Rijnland, en kennispartners Wageningen Environmental Research en Naturalis Biodiversity Center, wil graag de voor deze ambities benodigde partijen aan zich binden en een voorbeeld van wereldklasse zijn.

\section{'HEINEKEN}

HEINEKEN Nederland Contactpersoon Jan Kempers

Burgemeester Smeetsweg 1

2382 PH Zoeterwoude jan.kempers@heineken.com Telefoon +31 715456711 www.heinekennederland.nl

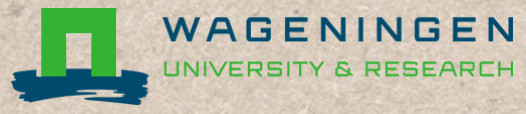

Alterra Wageningen UR

Contactpersoon Arjan Koomen

Droevendaalsesteeg 3

6708 PB Wageningen

eveliene.steingrover@wur.nl

telefoon +31317485874

www.wur.nl/environmental-research

\section{Hoogheemraadschap van}

\section{Rijnland}

Hoogheemraadschap van Rijnland Contactpersoon Marinus Bogaard

Postbus 156

2300 AD Leiden

marinus.bogaard@rijnland.net

www.rijnland.net

\section{Naturalis \\ Biodiversity center}

Naturalis Biodiversity Center

Contactpersoon Koos Biesmeijer

Postbus 9517

2300 RA Leiden

koos.biesmeijer@naturalis.nl

+31717519259

www.naturalis.nl

\section{Groene}

Cirkels

provincie HOLLAND

Provincie Zuid-Holland

Contactpersoon Linneke van Heemskerck-Duker

Zuid-Hollandplein 1

2509 LP Den Haag

I.van.heemskerckduker@pzh.nl

telefoon +31704418466

www.zuid-holland.nl
Groene Cirkel Bijenlandschap,

Omgevingsdienst West-Holland

Contactpersoon Hannie Korthof

Postbus 159

2300 AD Leiden

h.korthof@odwh.nl

Telefoon +31657974986

www.bijenlandschap.nl www.odwh.nl 
Voor het project 'Samen werken aan het Bijenlandschap' werkt Groene Cirkels samen met De Vlinderstichting, EIS en het Land van Wijk en Wouden.

De Vlinderstichting contactpersoon Anthonie Stip Mennonietenweg 10 6702 AD Wageningen anthonie.stip@vlinderstichting.nl telefoon 0317-467346 www.vlinderstichting.nl

EIS Kenniscentrum Nederland contactpersoon Menno Reemer Darwinweg 4 2300 RA Leiden menno.reemer@naturalis.nl telefoon 0717519359 www.eis-nederland.nl

Land van Wijk en Wouden contactpersoon Hannie Korthof Parkzicht 100

2317 RH Leiden h.korthof@odwh.nl telefoon 0652443166 www.landvanwijkenwouden.nl 


\section{Groene Cirkels}

\section{SAMEN WERKEN AAN HET BIJENLANDSCHAP}

Een klimaatneutrale HEINEKEN brouwerij, een duurzame economie én een aangename leefomgeving. Dat zijn de ambities waarvoor Groene Cirkels zich inzet. Dat doet zij door de natuur als uitgangspunt te nemen en programma's te realiseren rond de onderwerpen energie, water, grondstoffen, mobiliteit en leefomgeving. Het initiatief Groene Cirkels, gevormd door multinational HEINEKEN, provincie Zuid-Holland en kennispartner Alterra Wageningen UR, wil graag de voor deze ambities benodigde partijen aan zich binden en een voorbeeld van wereldklasse zijn.
Groene Cirkels koerst op een transitie naar duurzaam ruimtegebruik, met de verduurzaming van de HEINEKEN Brouwerij Zoeterwoude als vliegwiel.

Groene Cirkels dient als een platform voor bedrijven, ondernemers en kennisinstellingen in de regio. Partijen haken aan om hun eigen duurzame ambities en de gemeenschappelijke ambities binnen Groene Cirkels te verwezenlijken. Door het verbinden van de partijen worden de duurzaamheidsambities van de provincie versneld en worden er unieke projecten van wereldklasse ontwikkeld.

Zie ook www.groenecirkels.nl
Deze map met infobladen hoort bij de training 'Samenwerken aan het Bijenlandschap'.

Met deze training worden

diverse doelgroepen:

geënthousiasmeerd om mee te werken aan de realisatie van het bijenlandschap,

geïnformeerd over wat een bijenlandschap inhoudt en een handelingsperspectief gegeven om daadwerkelijk een bijdrage te leveren.
Elk infoblad correspondeert met een aantal slides in de presentatie die tijdens de training gegeven wordt. De infobladen zijn zowel samen als afzonderlijk te gebruiken.

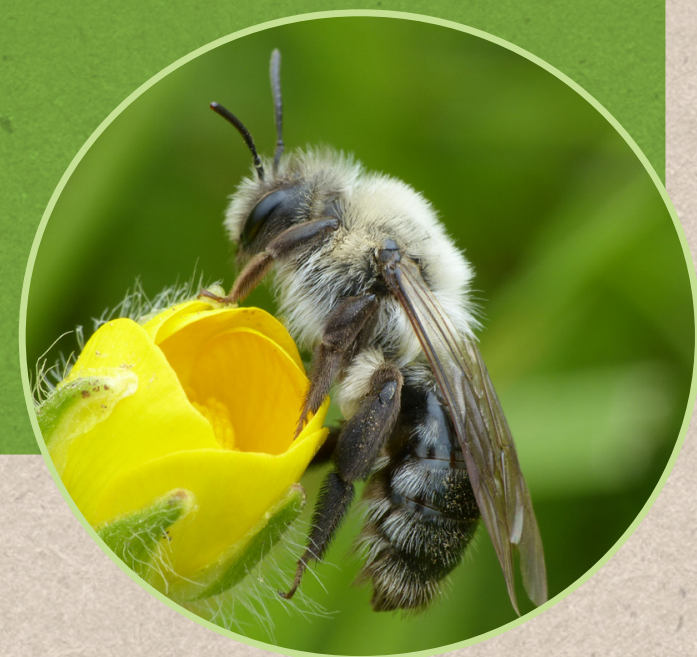




\section{Groene WAAROM EEN BIJENLANDSCHAP?}

\section{Bestuiving}

- $80 \%$ van de planten, zoals landbouwgewassen en wilde planten, in Nederland wordt bestoven door insecten.

- Van de 115 belangrijkste landbouwgewassen zijn er 87 afhankelijk van bestuiving door insecten.

- De economische waarde van bestuivers voor voedselproductie wordt geschat op:

- 15 miljard euro per jaar voor de EU,

- 153 miljard euro per jaar wereldwijd.

- Wilde bestuivers, zoals hommels en wilde bijen, vullen honingbijen goed aan en zijn in veel gevallen zelfs effectiever.
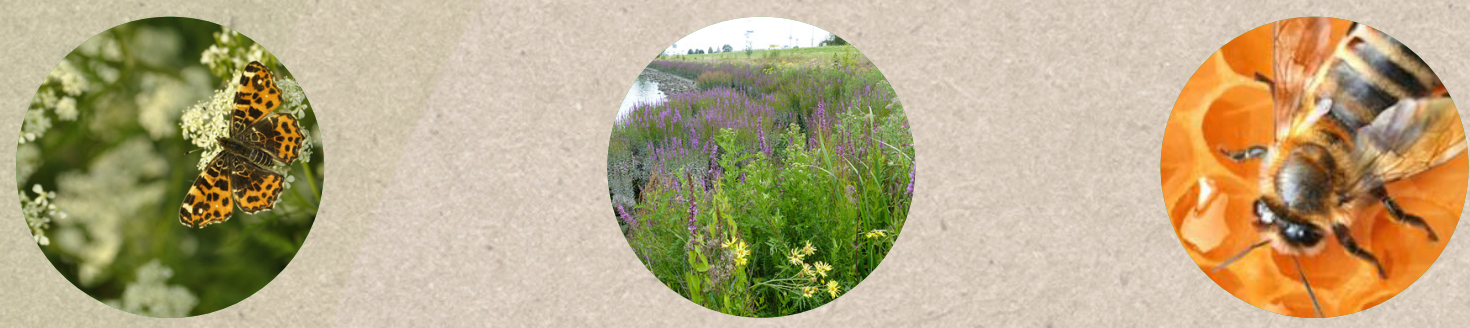

\section{Honingproductie}

Honing wordt geproduceerd door honingbijen.

De wintersterfte van volken honingbijen willen we terugbrengen naar minder dan $10 \%$.

\section{Aantrekkelijke, bloemrijke omgeving}

Een mooi, bloemrijk landschap draagt bij aan het welzijn van de mensen die er wonen en werken. Het verlaagt daarnaast ook het stressniveau.

\section{Let op!}

Een 'Bijenlandschap' is een landschap waar wilde bijen, honingbijen, zweefvliegen en vlinders voorkomen.
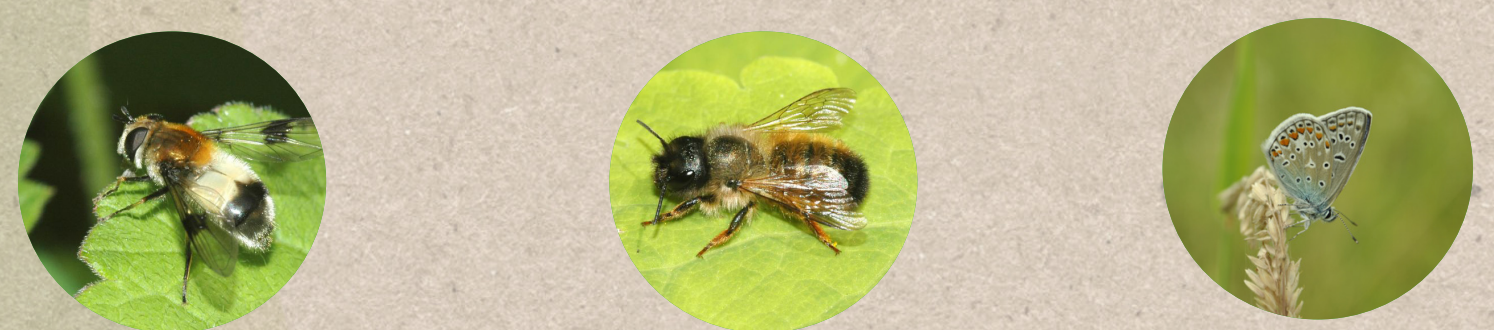

\section{SAMENVATTEND}

Het bijenlandschap levert:

- Bestuiving, belangrijk voor vrucht- en zaadvorming in (moes)tuinen, openbaar groen en natuur.

- Honing door honingbijen.

- Minder wintersterfte van de honingbijvolken.

- Een aantrekkelijke, bloemrijke leefomgeving. 


\section{Groene Cirkels \\ VOOR WELKE SOORTEN?}

\section{Bijen}

- 330 soorten wilde bijen in NL (excl. honingbij -> huisdier van imkers).

- Het zijn belangrijke bestuivers.

- Veel zijn specialisten in bloembezoek.

- Levenswijzen is zeer divers: bloembezoek, nestelplekken.

- Veel soorten zijn bedreigd.

- Honingbij: hoge wintersterfte in recente jaren.

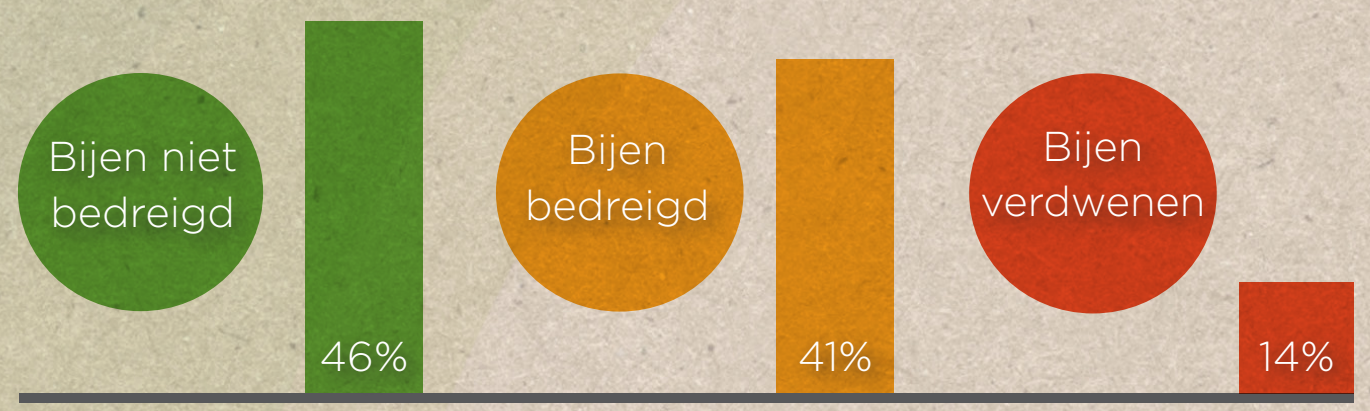

\section{Zweefvliegen}

- 330 soorten zweefvliegen in Nederland.

- Het zijn belangrijke bestuivers en bladluisbestrijders.

- De larven hebben een zeer diverse levenswijzen.

\section{Vlinders}

- 71 soorten dagvlinders in Nederland.

- 32\% bedreigd.

- Voedsel: nectar.

- De rupsen leven op diverse planten.

\section{Grote diversiteit aan soorten bestuivers}

Elke soort stelt andere eisen aan een leefomgeving (bloembezoek, nestelplekken etc.). Dus diversiteit in de leefomgeving is belangrijk, dat wil zeggen variatie in:

- plantensoorten,

- vegetatiestructuur (hoog/laag, dicht/spaarzaam),

- bodemreliëf (dijkjes/greppels, heuvels/kuilen),

- vochtigheid (nat/droog).

\section{SAMENVATTEND}

- 330 soorten wilde bijen: grote diversiteit, ook in levenswijzen.

- Meer dan helft soorten verdwenen of bedreigd.

- Honingbij: recent veel wintersterfte.

- 330 soorten zweefvliegen en 71 soorten vlinders.

- Zeer uiteenlopende wensen t.a.v. omgeving.

- Leefomgeving moet daarom zo divers mogelijk zijn.
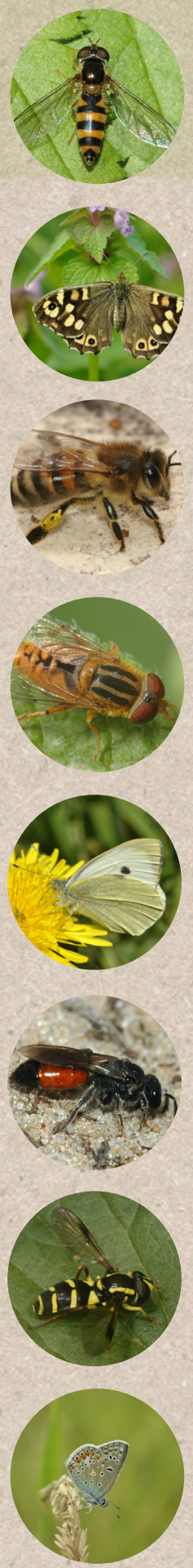


\section{Groene Cirkels}

\section{HET LANDSCHAP DOOR DE OGEN VAN BESTUIVERS}

\section{Bijen}

\section{Nestelplek}

- Open, zandige plekjes,

- zonbeschenen hellingen,

- struweel met overjarige takken,

- dood hout (inclusief bijenhotels).

\section{Voedsel (bloemen)}

- Variatie in plantensoorten.

- Variatie in bloeitijd.

- Bloei van vroeg voorjaar tot in nazomer.

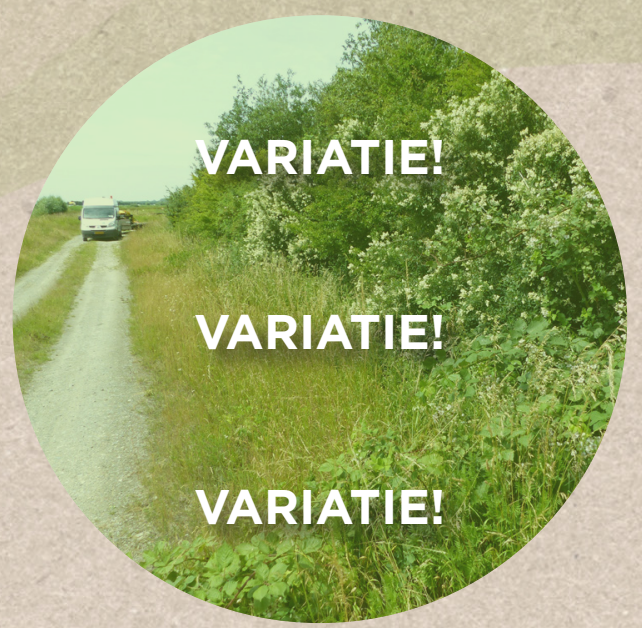

\section{Zweefvliegen \& dagvlinders}

- Niet gebonden aan nestelplekken.

\section{Voorbeelden van nestelplekken:}
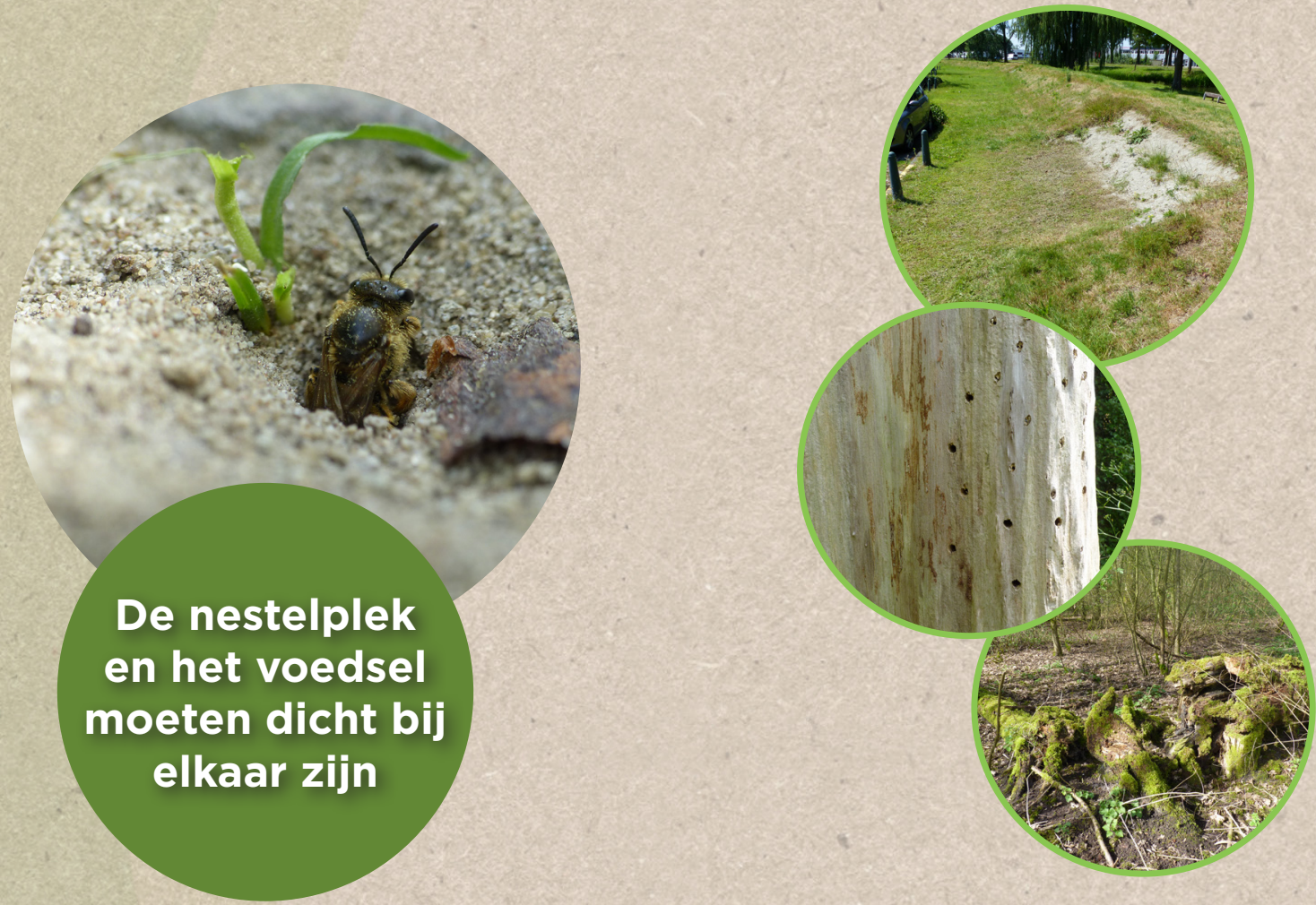

\section{SAMENVATTEND}

- Bijen hebben een centrale nestelplek nodig met voedsel binnen vliegbereik.

- Zweefvliegen en dagvlinders zijn niet gebonden aan vaste nestelplekken

- Kleinschalig landschap is belangrijk: er is veel variatie in bodemreliëf,

- Vegetatiestructuur en bloemenrijkdom nodig. 


\section{Groene Cirkels}

\section{VERSCHILLENDE \\ LANDSCHAPSTYPEN, VERSCHILLENDE BESTUIVERS}

Elk landschapstype heeft zijn soorten bestuivers die er voor kunnen komen. Veel bestuivers kunnen ook in meer dan één landschapstype voorkomen. De bestuivers van die voorkomen op laagveen en zeeklei hebben een grote overlap. In deze training verwijzen we naar de combinatie van deze landschappen, zoals dat voorkomt in het Land van Wijk en Wouden, als 'Laagveenlandschap'.

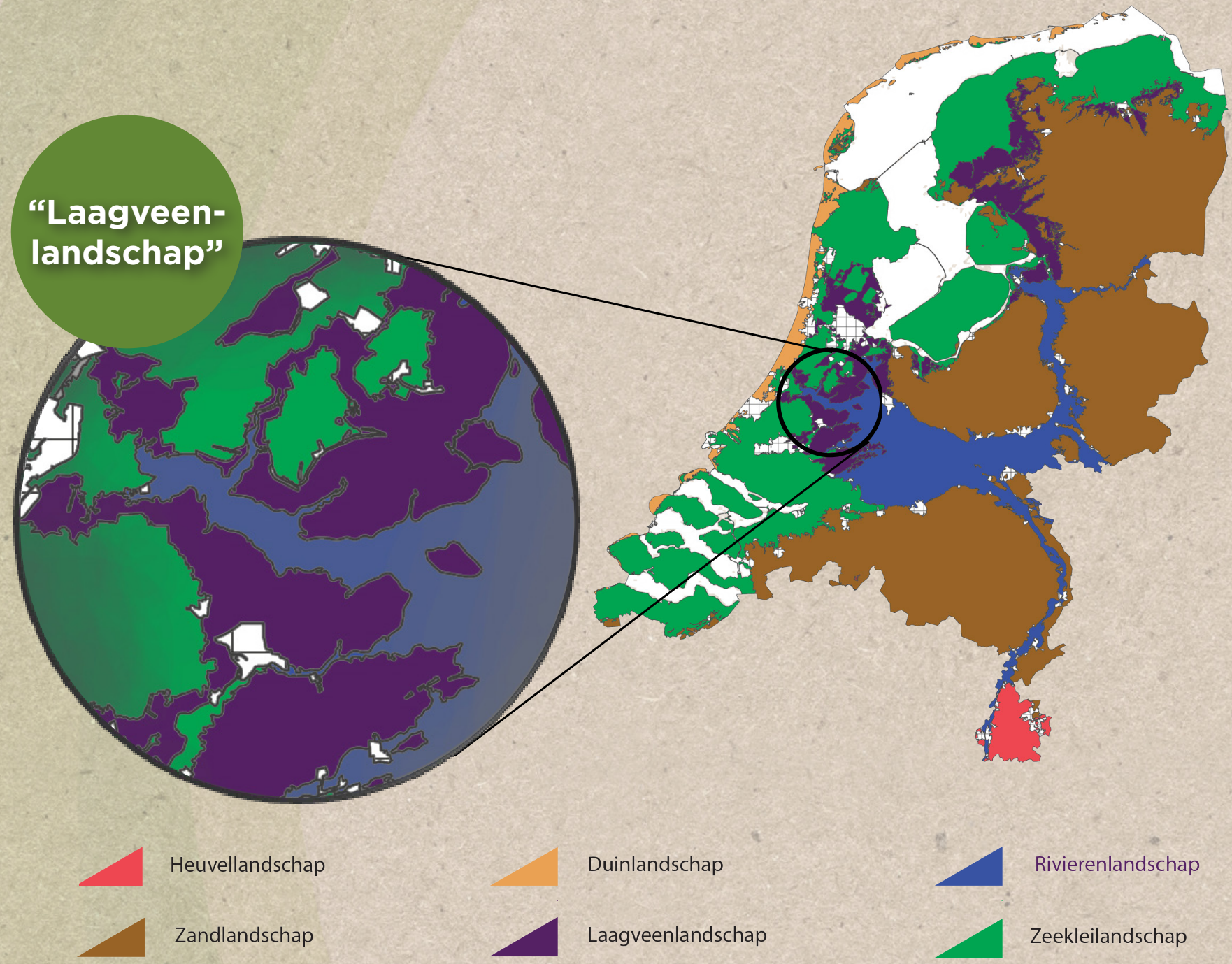




\section{Groene Cirkels}

\section{BINNEN ÉÉN LANDSCHAP: VERSCHILLENDE VEGETATIE, VERSCHILLENDE BESTUIVERS}

Ook binnen een landschap zijn groepen bestuivers te onderscheiden die elk hun leefgebied vinden in een ander vegetatietype. Voor elk van deze groepen ("Ecoprofielen") zijn bouwstenen voor het bijenlandschap ontwikkeld.

Elk landschapstype heeft zijn eigen set van bouwstenen. Door in een gebied alle bouwstenen van het betreffende landschapstype te realiseren, weet $u$ dat het plaats biedt aan het overgrote deel van de soorten die in het landschap kunnen voorkomen.

Een bouwsteen is een hulpmiddel en versimpelt de eisen van bestuivers aan hun leefgebied. Van een bouwsteen profiteren zo'n $80 \%$ van bestuivende soorten die in het leefgebied voor zou kunnen komen. De overige $20 \%$ soorten hebben specifieke wensen, zoals de aanwezigheid van bepaalde planten. Een gebied met een stevig netwerk van bouwstenen biedt een goede basis om voor deze soorten aanvullende maatregelen te kunnen nemen.

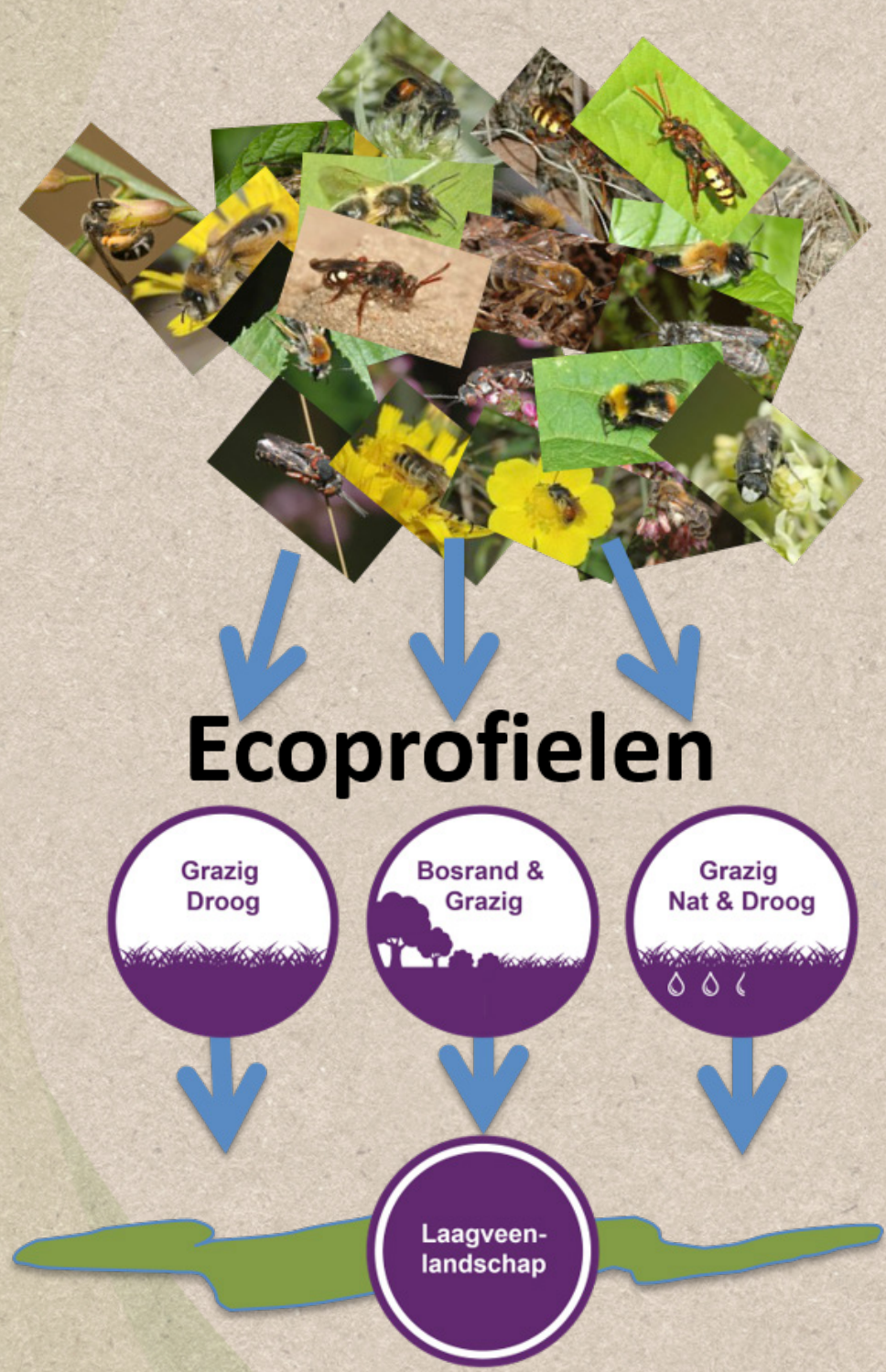




\section{Groene Cirkels \\ BOUWSTENEN VOOR HET LAAGVEENGEBIED}

Met behulp van deze bouwstenen wordt het bijenlandschap een regionaal netwerk voor bestuivers:

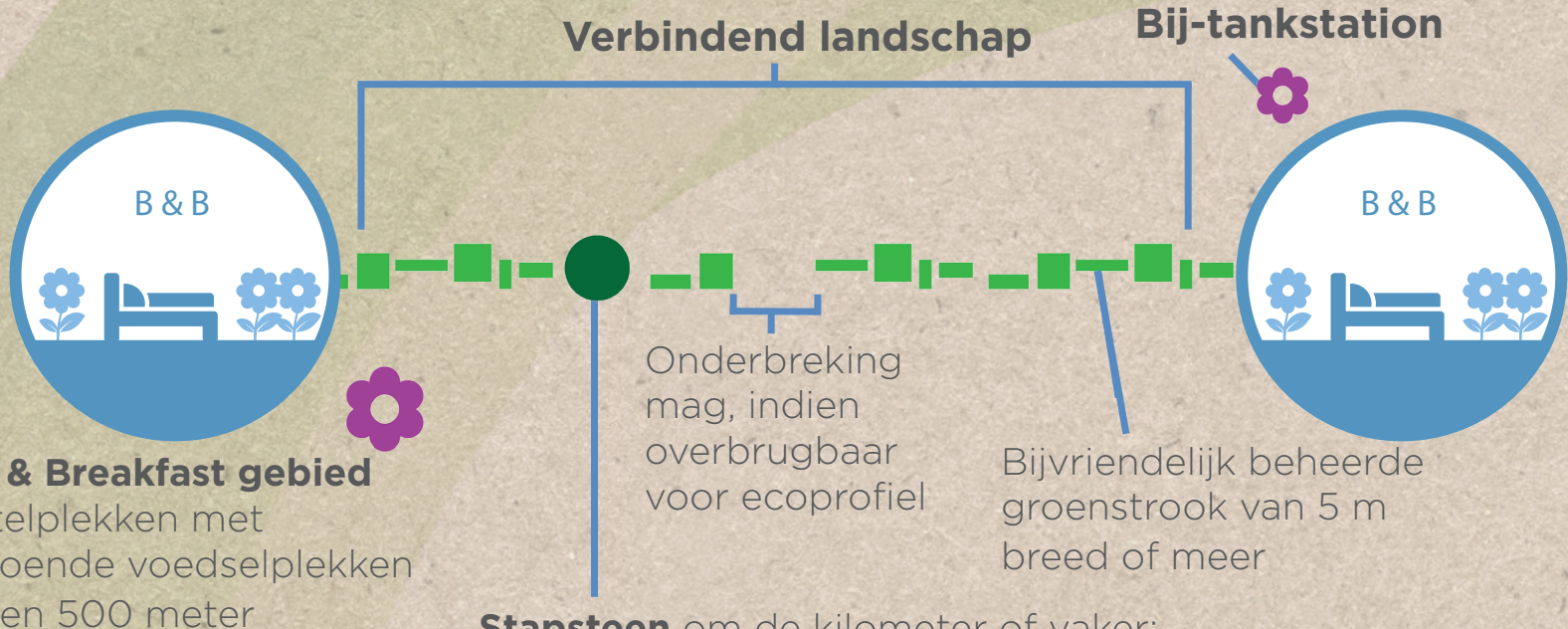

Stapsteen om de kilometer of vaker:

$(+/-10 \%$ binnen $1 \mathrm{~km} 2)$

0,5 ha (of meer) Bij- en vlindervriendelijk beheerd grasland

De verschillende soorten bestuivers zullen profiteren van 3 typen landschap:
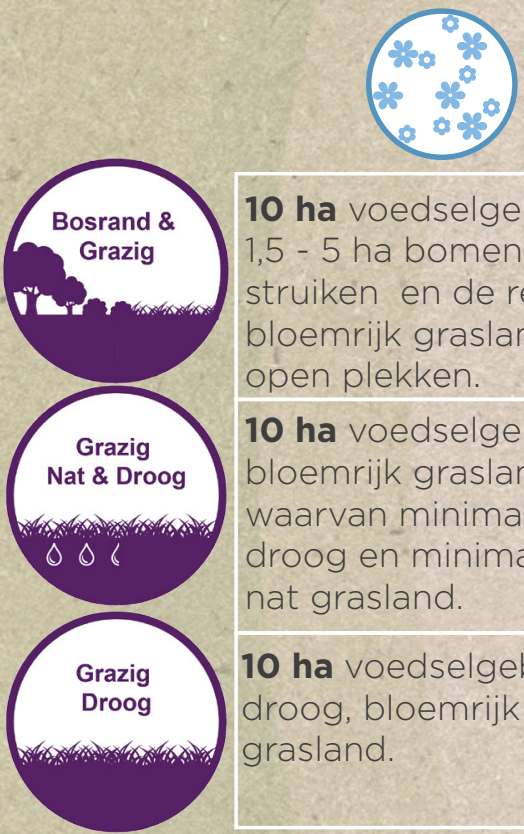

10 ha voedselgebied: 1,5 - 5 ha bomen of struiken en de rest bloemrijk grasland met open plekken.

10 ha voedselgebied: bloemrijk grasland, waarvan minimaal 2 ha droog en minimaal 2 ha nat grasland.

10 ha voedselgebied: droog, bloemrijk grasland

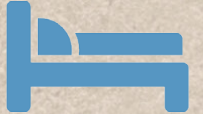

10 geschikte nestelplekken op grasland met kale plekken.

10 geschikte nestelplekken met variatie in de vochtigheid van de bodem.

\section{0 geschikte}

nestelplekken op droog grasland met kale plekken.
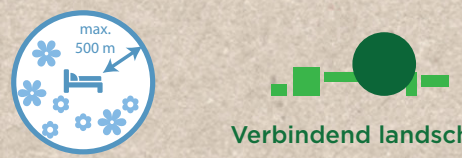

Verbindend landschap

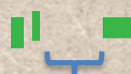

max. onderbreking in verbindend landschap

Minder dan

$\mathbf{5 0 0 m}$ afstand

tussen

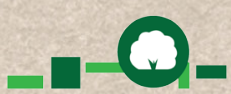

$100 \mathrm{~m}$

bed en breakfast.

Minder dan

500m afstand

tussen

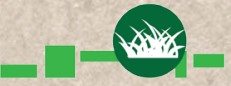

$100 \mathrm{~m}$

\section{Minder dan}

$\mathbf{5 0 0} \mathbf{m}$ afstand

tussen

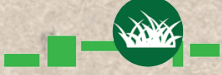

100m

\section{SAMENVATTEND}

Bed \& Breakfast gebied = een leefgebied voor gezonde populaties bestuivende insecten die tegen een stootje kunnen.

Verbindend landschap = een bloemrijke verbinding tussen Bed \& Breakfast gebieden. Bij-tankstation = Kleine bloemperkjes waar bestuivers die niet kieskeurig zijn kunnen bijtanken. 


\section{Groene Cirkels \\ BOUWSTENEN VOOR HET DUINENGEBIED}

Met behulp van deze bouwstenen wordt het bijenlandschap een regionaal netwerk voor bestuivers:

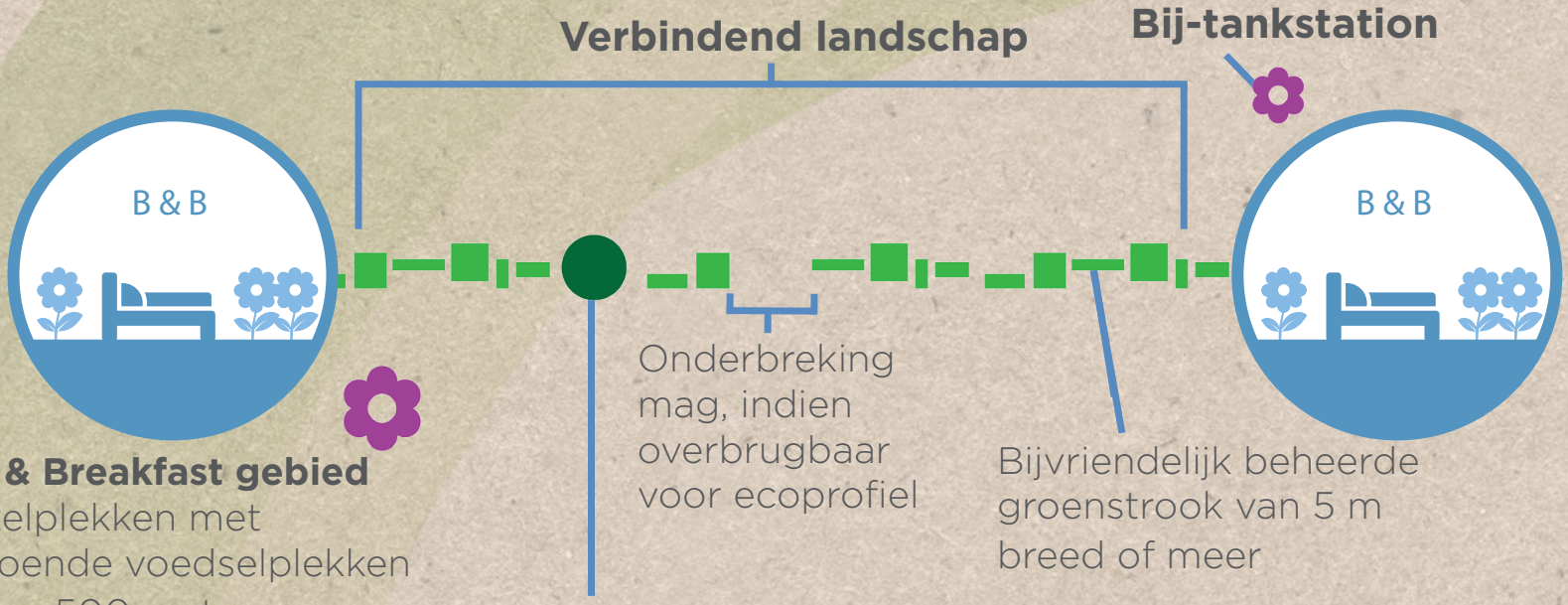

Stapsteen om de kilometer of vaker:

binnen 500 meter

$(+/-10 \%$ binnen $1 \mathrm{~km} 2)$

0,5 ha (of meer) Bij- en vlindervriendelijk beheerd grasland

De verschillende soorten bestuivers zullen profiteren van 5 typen landschap:

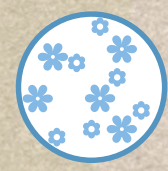

10 ha voedselhabitat: Reliëfrijke duinen met mozaïek van zand, bloemrijke grazige vegetatie en solitaire bomen / stuiken

10 ha voedselgebied: droog, bloemrijk grasland

10 ha voedselgebied: bloemrijke grasland/ moeras, waarvan minimaal 2 ha droog en minimaal 2 ha nat

10 ha voedselhabitat: 1,5 tot 5 ha bos of struweel, de rest bloemrijke grazige vegetatie

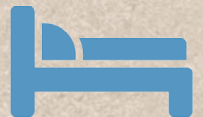

10 geschikte nestelplekken met reliëfrijke duinen met open zand en steilrandjes

10 geschikte nestelplekken op droog grasland met kale plekken

\section{0 geschikte} nestelplekken met variatie in de vochtigheid van de bodem

\section{0 geschikte} nestelplekken In bosranden en grazig vegetatie met kale plekken

10 ha structuurrijk bos, inclusief struweel, zonbeschenen bospaden en open plekken, waarvan minimaal 2 ha bos van ten minste 50 jaar oud
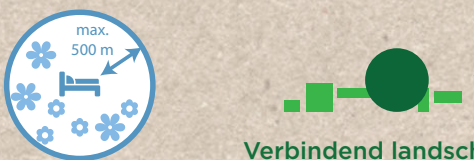

Verbindend landschap

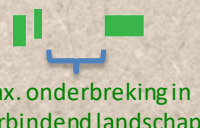

Minder dan 250m

afstand tussen

bed en breakfast

$50 \mathrm{~m}$

Minder dan

500m afstand

tussen

bed en breakfast.

Minder dan

500m afstand

tussen

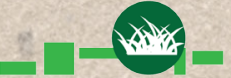

$100 m$

bed en breakfast.

Minder dan

$\mathbf{5 0 0 m}$ afstand

tussen

bed en breakfast.

$100 m$

Voldoende

habitat binnen straal van 500m

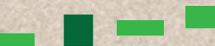

$500 \mathrm{~m}$ 


\section{Groene BIJ-VRIENDELIJKE Cirkels INRICHTING}

\section{Kleinschalig, mozaïek landschap}

- Bodemreliëf (heuvels, richels, dijkjes, greppels).

- Gevarieerde vegetatiestructuur: kruiden, struweel, bomen).

- Niet te netjes!

\section{Aandacht voor nestelplaatsen}

- Creëer een kale bodem op zonnige, bij voorkeur steile plekken.

- Zorg voor overjarig struweel en dood hout (boomstronken).

- Dood hout niet mogelijk? Dan bijenhotels!
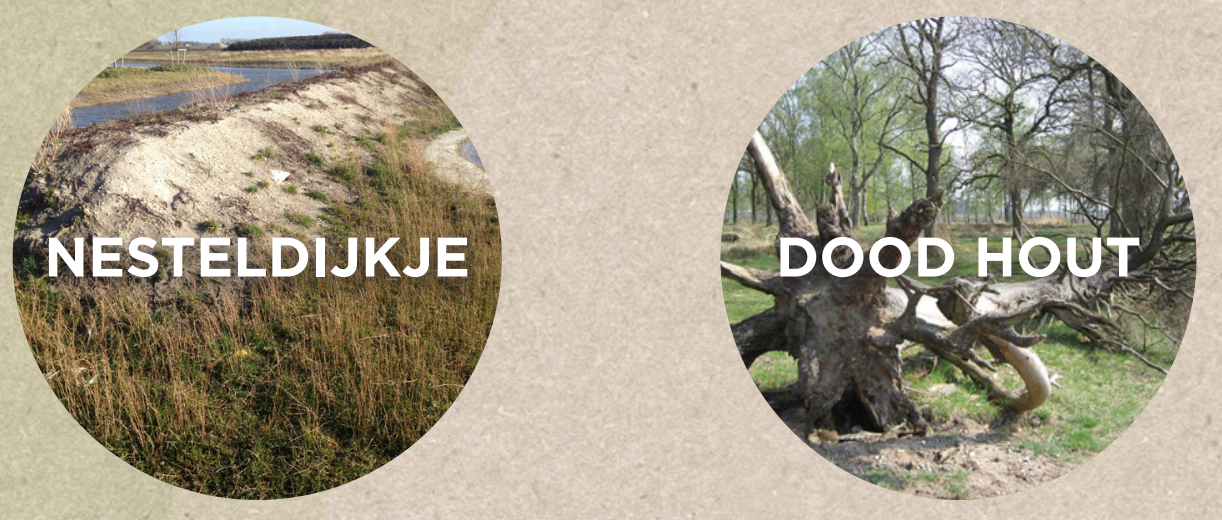

\section{Bloemrijk in alle seizoenen Voorbeelden:}

- Voorjaar: wilgen, sleedoorns, (vogel)kers, meidoorn, lijsterbes.

- Zomer: vuilboom, liguster, linde. Kruiden: diverse lipbloemen, vlinderbloemen, composieten, schermbloemen, etc.

- Nazomer: klimop, in tuinen bijv. ook herfstaster, persica.

De plantensoorten zijn slechts een greep aan het groot aantal mogelijkheden. 


\section{Groene \\ BIJ-VRIENDELIJKE BERMEN}

Cirkels

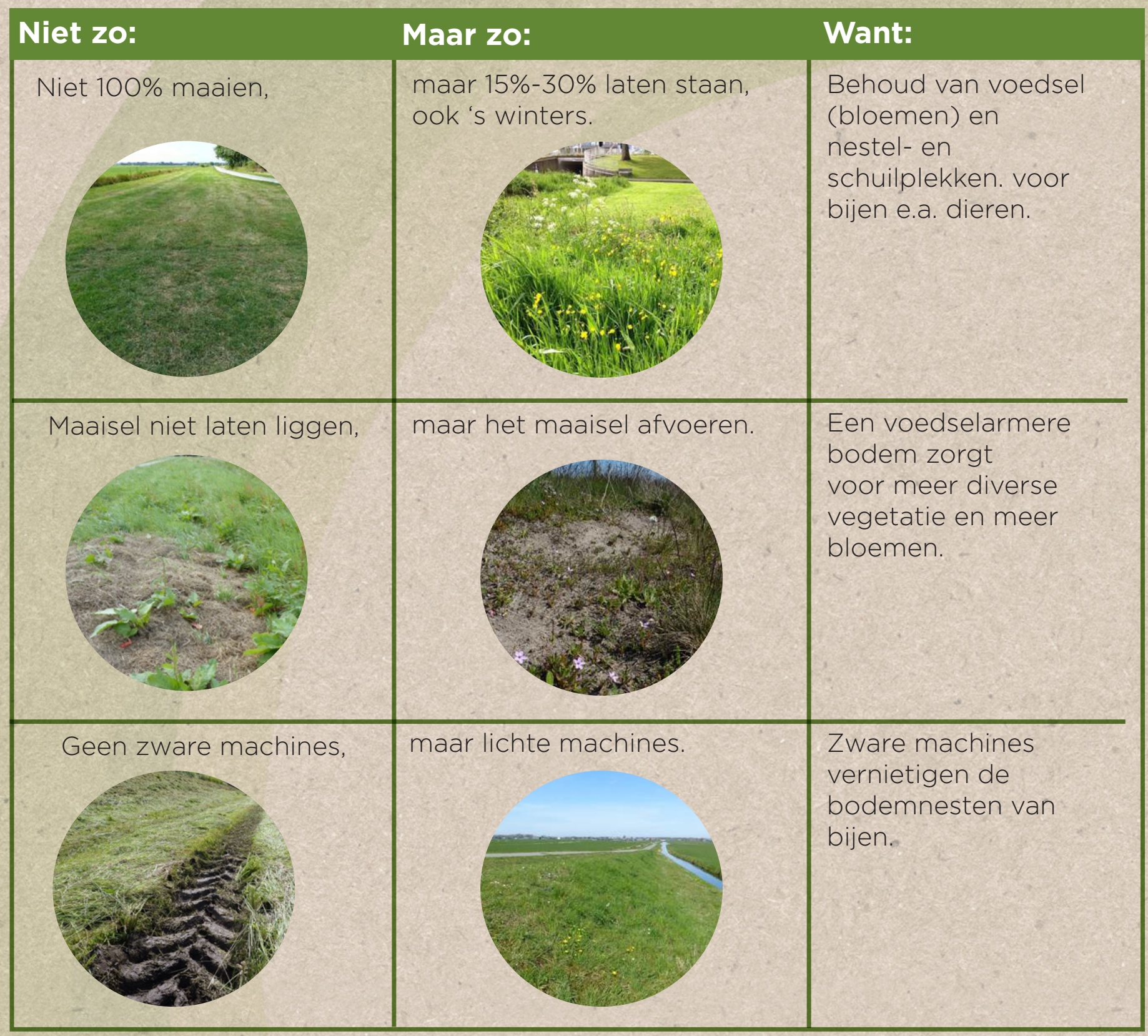

\section{SAMENVATTEND}

- Gefaseerd maaien: altijd min. 15\% - 30\% laten staan.

- Maaisel afvoeren.

- Licht materiaal gebruiken. 


\section{Groene \\ BIJ-VRIENDELIJKE TUINEN}

Cirkels

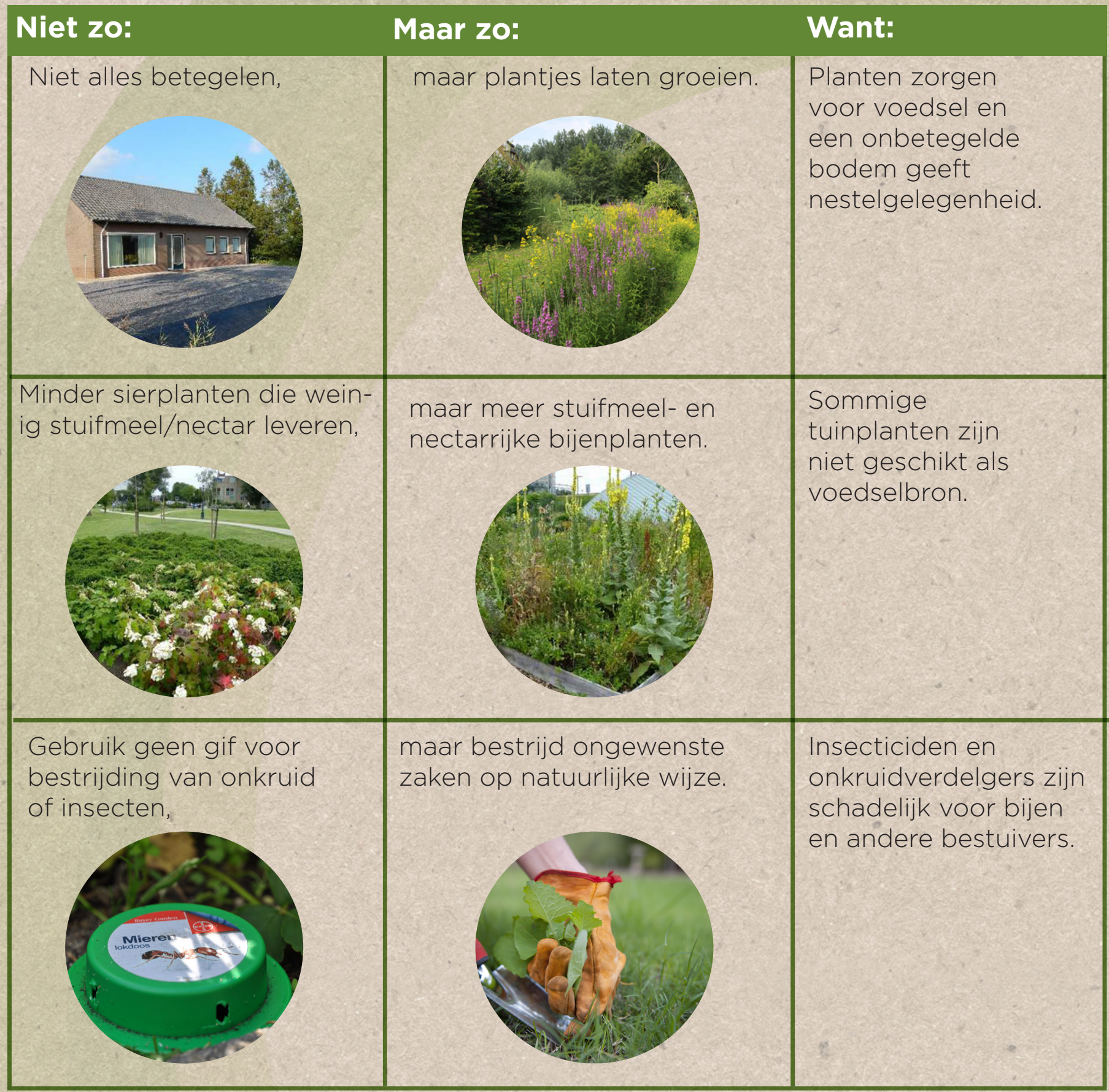

\section{SAMENVATTEND}

- Vervang tegels en grind door bloeiende planten.

- Zo veel mogelijk stuifmeel- en nectarrijke 'bijenplanten'.

Meer informatie over bijenplanten:

- https://www.wegwijzerbestuivers.nl/ 


\section{Groene Cirkels}

\section{BIJ-VRIENDELIJKE TUINEN nestelplekken}

Natuurlijke, zonnige nestelplekken

- Dood hout belangrijk (vooral staand!).

- Oude, holle stengels (braam, vlier, riet).

- Kale, zonbeschenen bodem, niet omgeschoffeld (hoe steiler, hoe beter).

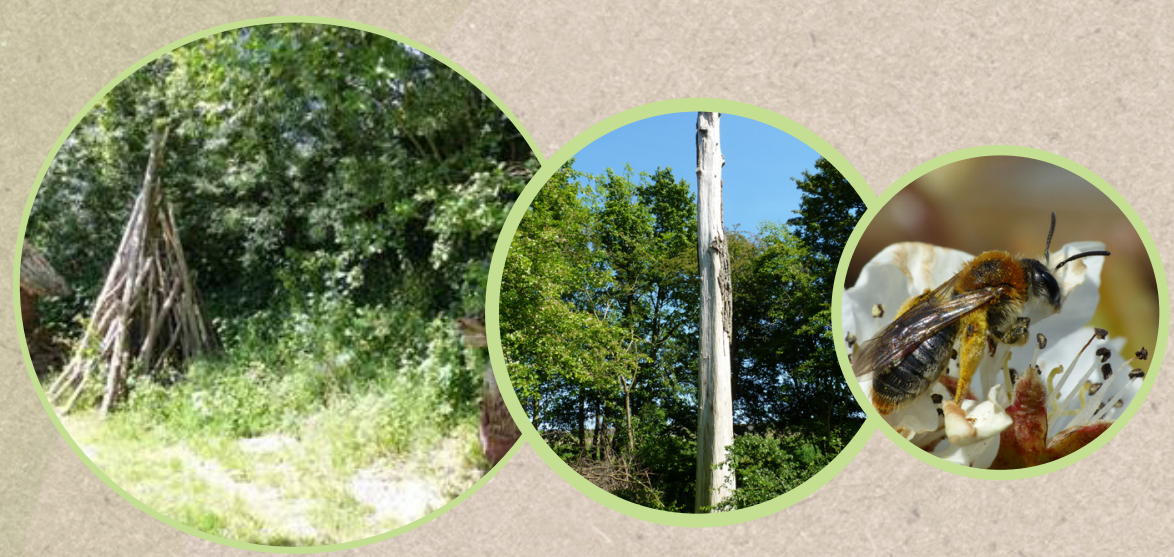

\section{Kunstmatige nestelplekken}

- Bijenhotels, doe het goed! Zie www.bestuivers.nl

- Lemen wanden.

- Rieten daken.

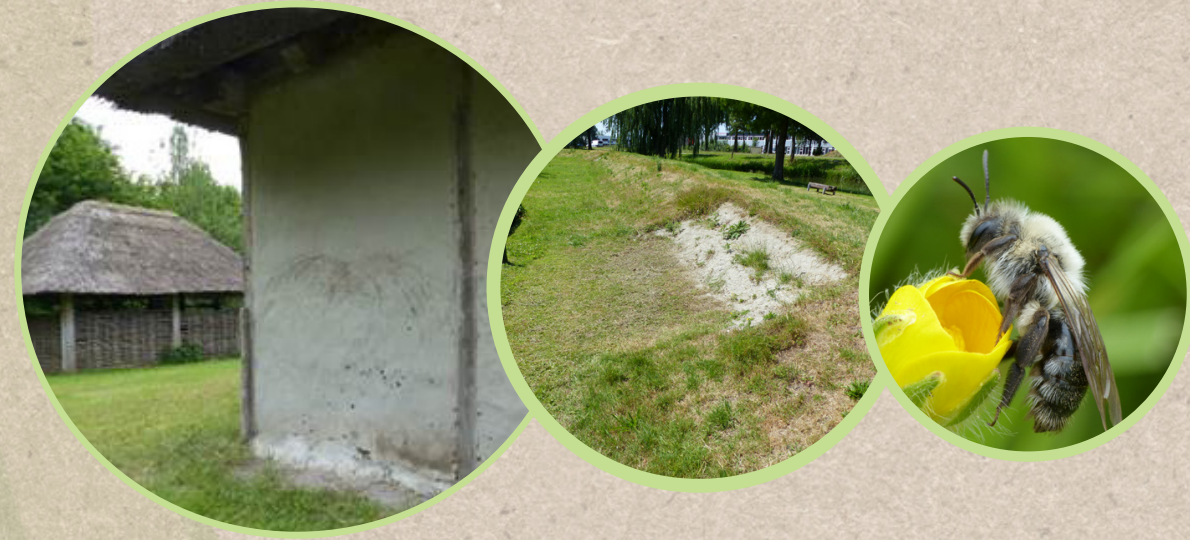




\section{Groene Cirkels}

\section{BIJ-VRIENDELIJKE TUINEN een bijenhotel}

\section{Een goed bijenhotel}

- Op een zonnige plek.

- Diameter van de gaten en stengels is 3-8 $\mathrm{mm}$.

- Gangen aan de achterzijde dicht (bijv. met watten of klei).

- Gebruik hard hout (beuk, eik, es, esdoorn).

- Plantenstengels met zachte merg (braam, vlier).

- Maak een afdakje tegen de instromende regen.

- Verticaal geplaatste bakken met leem/klei goed voor andere soorten.
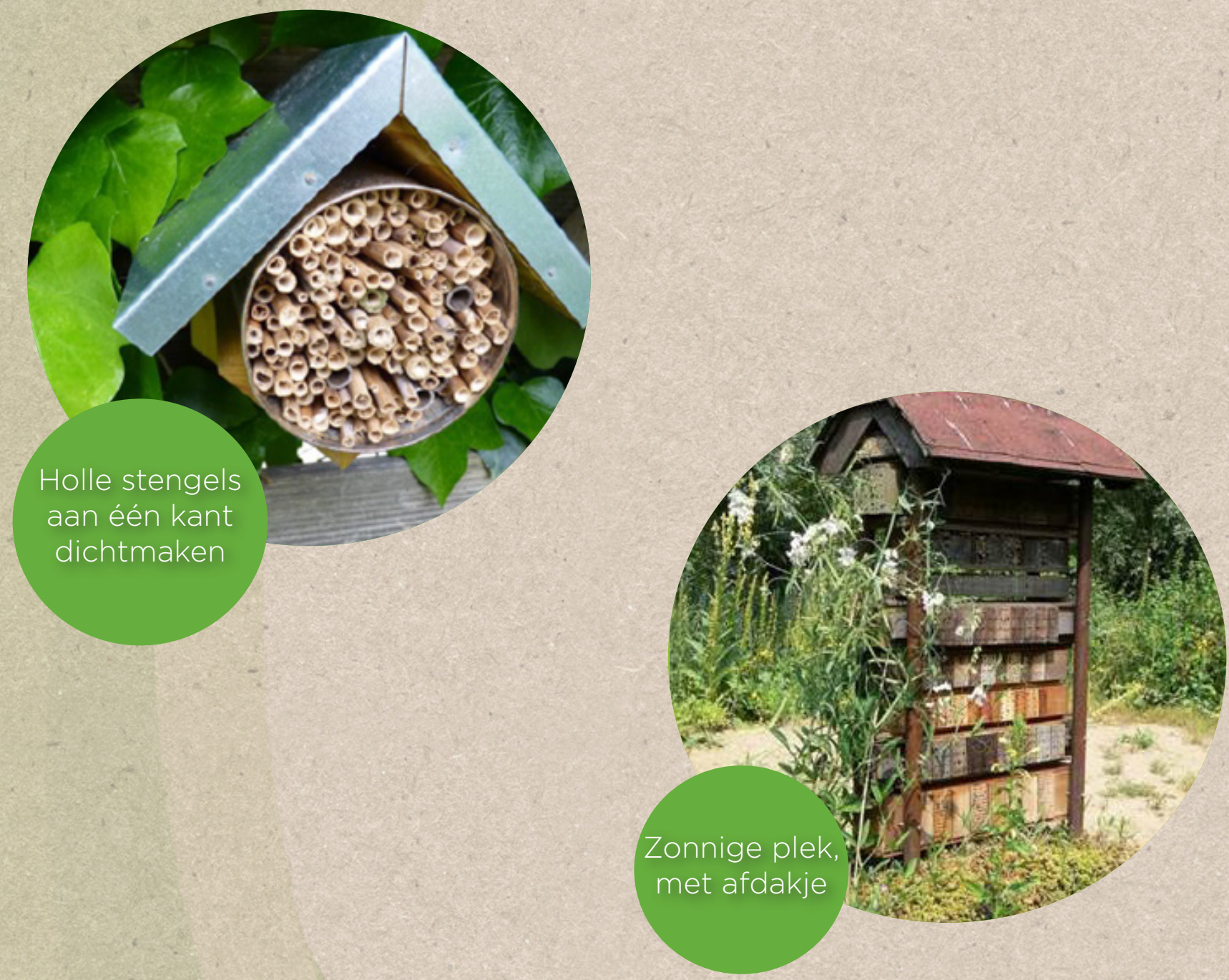


\section{Groene Cirkels}

\section{BIJ-VRIENDELIJKE BEDRIJVENTERREINEN}

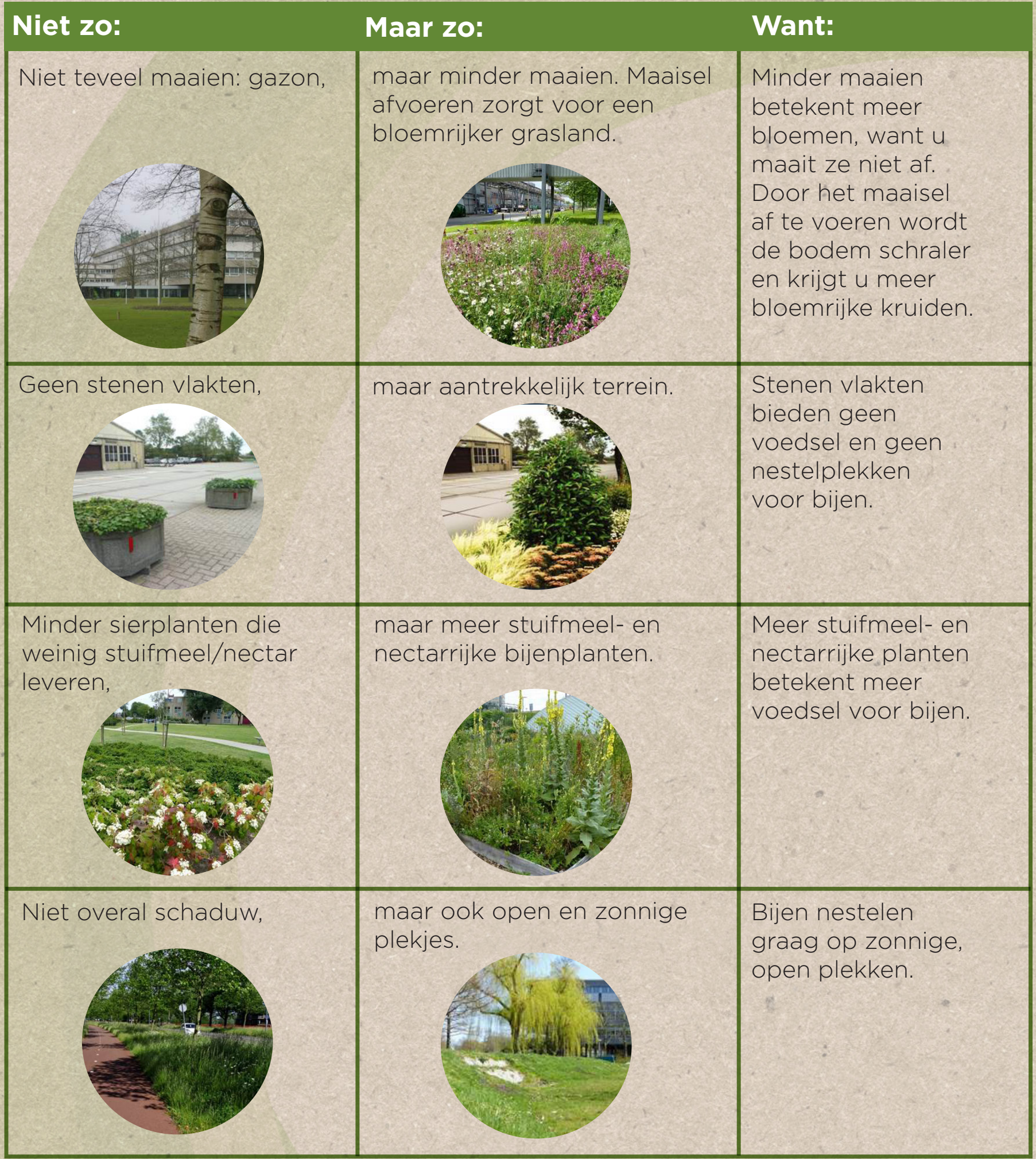

\section{SAMENVATTEND}

- Richt u op bloemen in plaats van op gras.

- Vervang onnodige stenen voor aantrekkelijk groen.

- Gebruik planten die veel stuifmeel en nectar leveren.

- Zorg voor zonnige nestelplekken (kale grond, dood hout). 


\section{Groene Cirkels}

In het openbaar groen zijn er door bijvriendelijke inrichting en beheer veel kansen te verzilveren voor het bijenlandschap.

\section{Inrichting}

\section{Plant inheemse bomen, struiken en kruiden.}

Deze soorten bieden bijen voedsel- en nestelgelegenheden. Een mix van vroeg- en laatbloeiende soorten werkt het best: dan is er voor bijen en andere insecten gedurende het grootste deel van het jaar voedsel te vinden.

- Vroege bloeiers: diverse wilgensoorten, gele kornoelje, spaanse aak, sleedoorn.

- Voorjaar/vroege zomer: meidoorn, zoete kers, linde. fruitbomen.

- Late bloeiers: braam, klimop.

Stem de beplantingskeuze altijd af met het bodemtype en lokale (grond)waterstand. Dit is in hoge mate bepalend voor het 'aanslaan' van de beplanting.

\section{Beheer}

\section{Maai gefaseerd.}

Bij elke maaibeurt dient minimaal 15\% - 30\% van het vegetatie-oppervlak te blijven staan. Zo blijven er gedurende het seizoen meer bloemen en nestelplekjes aanwezig.

\section{Werk kleinschalig.}

Houd rekening met de variatie die in een terrein aanwezig is en houd deze ook in stand. Te denken valt aan reliëf en variatie in hoogte en de structuur van de vegetatie. Creër of koester geleidelijk overgangen (gradiënten): hoog-laag, nat-droog, voedselrijk-voedselarm enzovoorts.

\section{Gebruik geen chemische bestrijdingsmiddelen.}

Het gebruik van onkruidverdelgers, herbiciden, roundup en andere bestrijdingsmiddelen is sterk te ontraden. Dit is schadelijk voor bijen en andere insecten. Er zijn bijvriendelijke alternatieven voorhanden (zie slide 'Onkruidbestrijding').

\section{SAMENVATTEND}

- Niet alles betegelen, maar planten laten groeien.

- Minder sierplanten, meer bijenplanten.

- Gebruik geen gif. 


\section{Groene \\ WERKTUIGEN}

Cirkels

Niet alle werktuigen zijn geschikt voor bijvriendelijk beheer, hieronder ziet $u$ een overzicht van de werktuigen en de geschiktheid van toepassinging daarvan in het bijenlandschap.

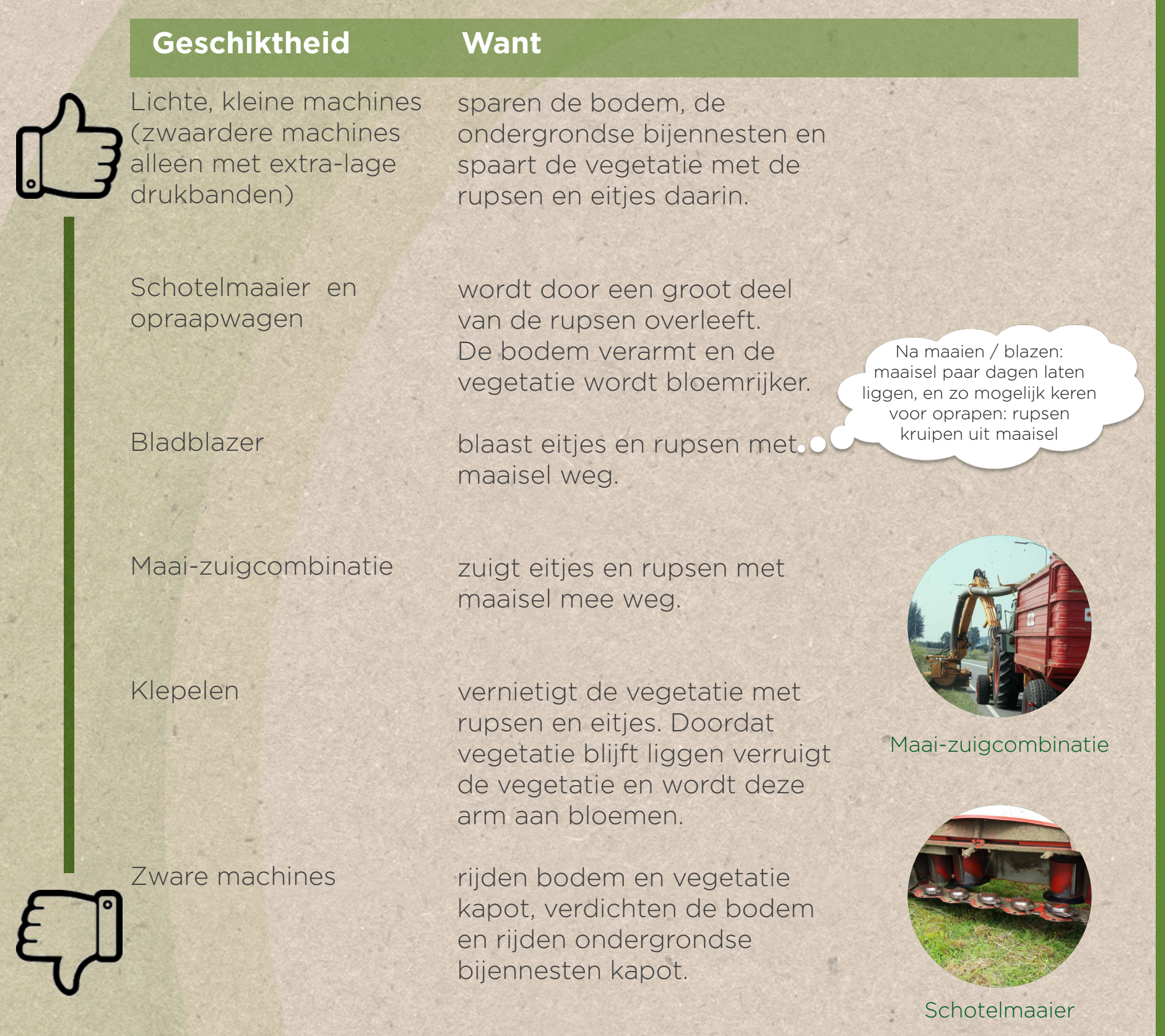

\section{SAMENVATTEND}

- Gebruik bij voorkeur de schotelmaaier en opraapwagen.

- Maaisel enkele dagen laten liggen.

- Niet klepelen!

- Gebruik lichte machines (of extra-lage drukbanden).
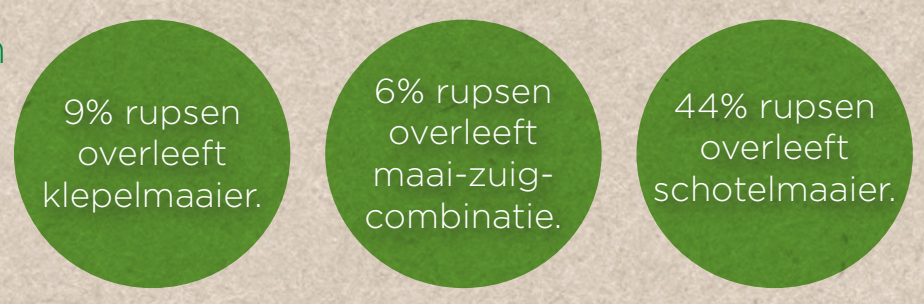


\section{Groene Cirkels}

\section{ONKRUID- EN \\ PLAAGBESTRIJDING}

"Onkruid" kan ook gunstig zijn in een bijviendelijk landschap. Voor gerichte bestrijding van plantensoorten waar u echt last van heeft geldt: voorkomen is beter dan genezen.

\section{Onkruid in beplanting en gras}

- Goed maai- of schoffelbeheer: hiermee zijn onkruiden vaak prima te reguleren.

- Vraag u af of u overal zwarte grond om de planten wilt hebben. Bedek open grond met bodembekkende planten om groei van onkruid tegen te gaan, of schoffel.

- Soms is er gerichte bestrijding nodig van soorten. Gebruik dan niet-chemische alternatieven zoals bestrijden met heet water, uitsteken. Belangrijk is om dit soort moeilijke onkruiden in een vroegtijdig stadium aan te pakken.

\section{Onkruid op verhardingen}

- Voorkom ongewenste plantengroei door een goed ontwerp. Zorg ervoor dat de verharding ligt op logische loop-en fietsroutes. Door betreding en berijding komt veel minder onkruid op.

- Verminder het aantal voegen in de bestrating en zorg dat tegels goed aansluiten.

- Verwijder onkruid mechanisch (voegenkrabber op terras of oprit, bosmaaier, borstelmachine)

- Bestrijd thermisch met een onkruidbrander, heet water of hete lucht.

- Werk met een integraal bestek waarin ook veegbeheer is ondergebracht. Dan kan een aannemer flexibeler en kosteneffectiever werken.

- Door een meerjarig beeldbestek kan een aannemer ook efficiënter werken. De, kosten van niet-chemisch onkruidbeheer zijn op termijn vergelijkbaar met de kosten van chemisch beheer.

Begin 2016 zijn er strenge wettelijke beperkingen aan gebruik van chemische bestrijdingsmiddelen buiten de landbouw van kracht. Het gebruik van Glyfosaat (Roundup) is hiermee verboden.

- Zie voor gerichte bestrijding van ongewenste soorten: httos://www.barometerduurzaamterreinbeheer.nl/124/voor-terreinbeheerders/ twee-niveaus.html

Chemische

bestrijdingsmiddelen

tegen slakken

insecten, zoals

slakkenkorrels en

mierenlokdoosjes zijn

erg schadelijk voor

bijen en vlinders-en ook

voor de mens.

\section{SAMENVATTEND}

- Met goed maai- of schoffelbeheer is onkruid vaak onder controle te houden.

- Gebruik zo min mogelijk bestrijdingsmiddel of gewasbeschermingsmiddel, maar duurzame alternatieven zoals heet water, hete lucht, onkruidbrander of een borstelmachine.

- Zie ook: www.crow.nl/vakgebieden/openbare-ruimte/beheer-en-onderhoud/onkruid-verhardingen/ 


\section{Groene Cirkels}

\section{CONTOUREN VAN HET BIJENLANDCHAP IN BEELD}

De bouwstenen geven de mogelijkheid om op kaart zichtbaar maken welke bouwstenen waar in een gebied aanwezig zijn.

In 2017 en 2018 is met actoren in de 5 kerngemeenten (Alphen aan den Rijn, Leiden, Leiderdorp, Zoetermeer en Zoeterwoude) informatie over de kwaliteit van het landschap voor bestuivers verzameld. Hiermee is een kaart gemaakt die laat zien welke plekken voldoen aan de randvoorwaarden voor Bed \& Breakfast-gebieden en Verbindend Landschap.

Met deze kaart kunnen strategische keuzes gemaakt worden voor de verdere versterking van het bijenlandschap.

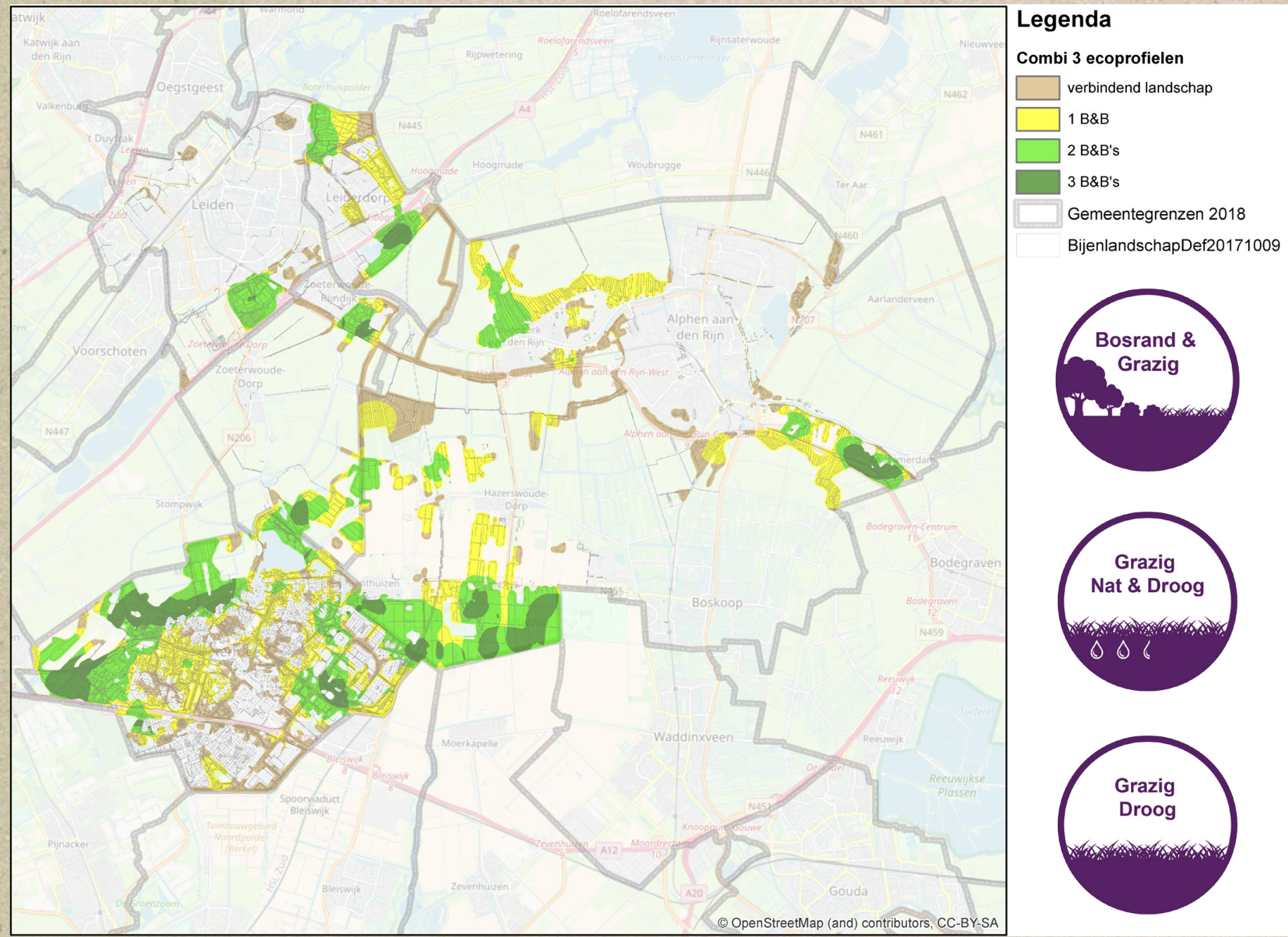




\section{Groene Cirkels}

\section{KOSTEN EN BATEN}

In de brochure KOSTEN EN BATEN BIJVRIENDELIJK

BEHEER worden verschillende vormen van bijvriendelijk beheer met traditioneel beheer vergeleken.

De brochure biedt bestuurders, ambtenaren en beheerders inspiratie en concrete handvatten om traditioneel beheer van openbaar groen om te vormen naar meer bijvriendelijke vormen.

De onderstaande tabel geeft een voorbeeld van de informatie in deze brochure.

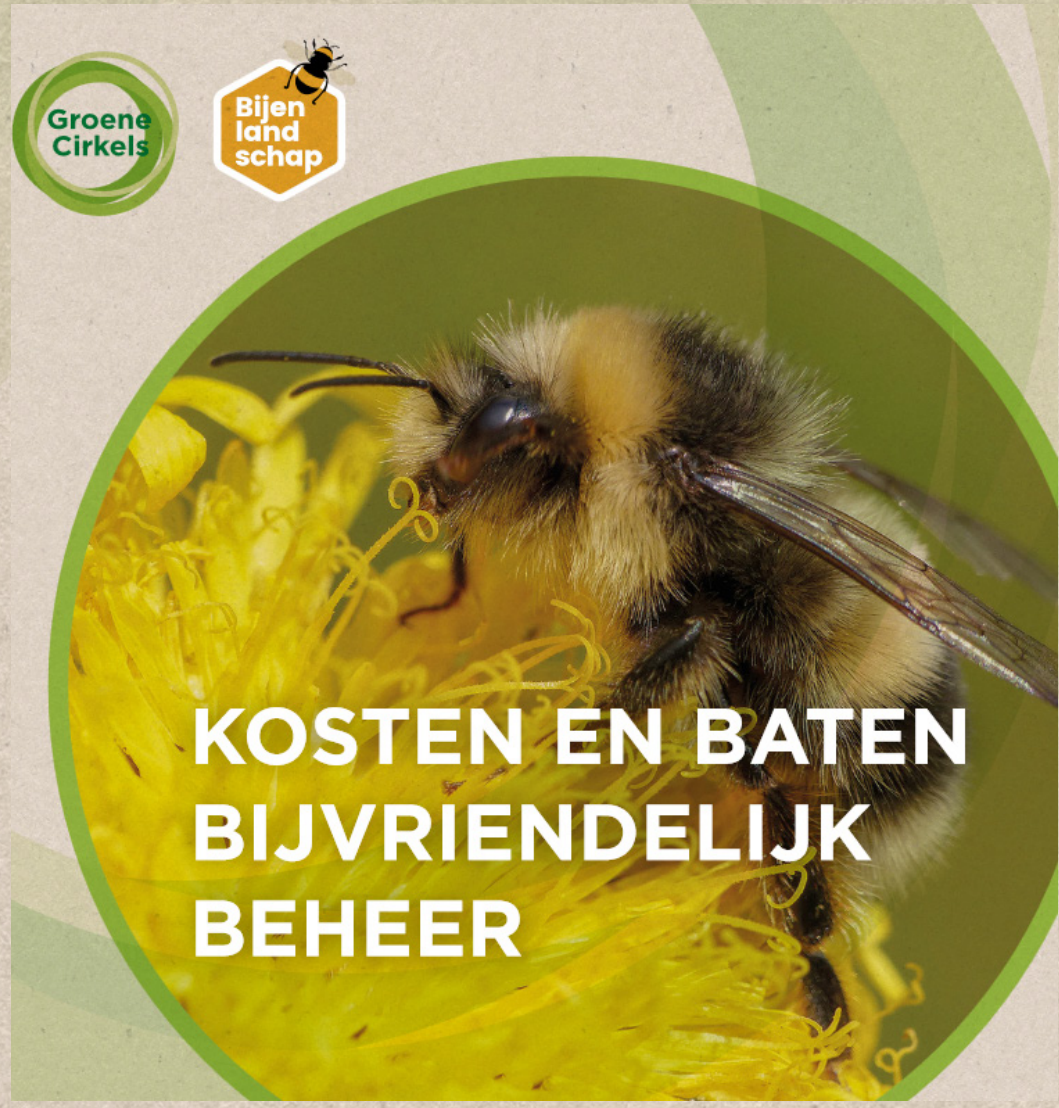

\begin{tabular}{l|c} 
Type beheer & Kosten er $\mathrm{m}^{2}$ per jaar \\
$\begin{array}{l}\text { Ruw gras }- \text { riendelijk? } \\
\text { Klepelen en laten liggen }\end{array}$ & $0,04-0,07 €$ \\
\hline Gazonmaaien, $20 \times$ per jaar & $0,21-0,35 €$ \\
\hline $\begin{array}{l}\text { Bloemrijk gras, } 2 \times \text { per jaar maai-zuigen } \\
\text { Eloemrijk gras, gefaseerd gemaaid, } \\
\text { afvoeren }\end{array}$ & $0,10-0,17 €$
\end{tabular}




\section{Groene Cirkels}

\section{BATEN VAN HET BIJENLANDSCHAP}

"Bestuiving door hommels bespaart de Nederlandse tomatenteelt tussen de 12,9 en 38,1 miljoen euro per jaar." (TEEB voor bedrijven, 2012)

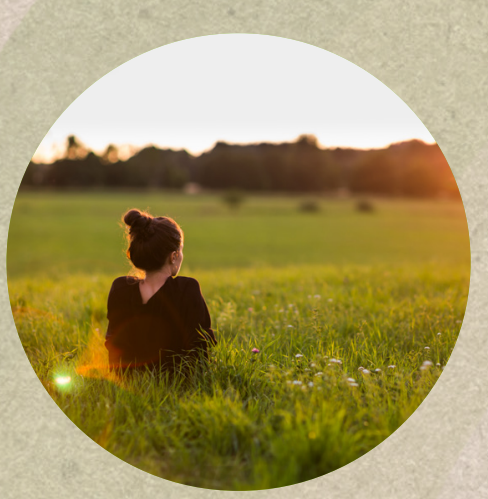

"Natuur nodigt uit tot buitenspelen. Kinderen die lekker in beweging zijn kunnen daarna beter leren." (IVN, Mark Mieras, 2015)

"Actief randenbeheer: Lagere kosten voor zuivering oppervlaktewater door minder bestrijdingsmiddelen." (CIW, 1999)

"In de Hoeksche Waard zijn de kosten voor de aanleg en het beheer van de natuur 89,2 miljoen euro, de gezamenlijke baten - waaronder de stijging van de huizenprijzen en de cultuurhistorische waarde en de voordelen door schoner oppervlaktewater -143,3 miljoen euro."(Melman et al. 2012)

\section{Stadspark Fens}

\section{Eenmalige baten: $\mathbf{C} \mathbf{8 0 1 . 7 0 0}$}

- Hemelwaterverwerking: $€ 85.500$

- Omgevingskwaliteit woningen: $€ 716.200$

\section{Jaarlijkse baten: C $\mathbf{1 1 5 . 1 0 1}$}

- Luchtkwaliteit: $€ 680$

- Omgevingskwaliteit woningen $€ 13.324$

- Omgevingskwaliteit kantoren $€ 10.286$

Exploitatie horeca $\subset 90.811$

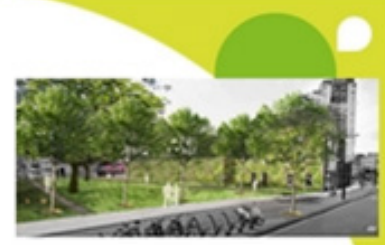

Investering $€ 1.227 .500$

Jaarlijkse kosten € 52.150

Terugverdientijd 6,5 jaar
"Natuurgebieden, parken, bomen en tuinen vormen een vluchtheuvel voor de geest. Er is robuuste wetenschappelijke steun voor deze veronderstelling."

(IVN, Mark Mieras, 2015)

"Mensen die in een groene omgeving wonen, voelen zich niet alleen gezonder, ze zijn het feitelijk ook." (Trouw, Jolanda Maas, 2012)
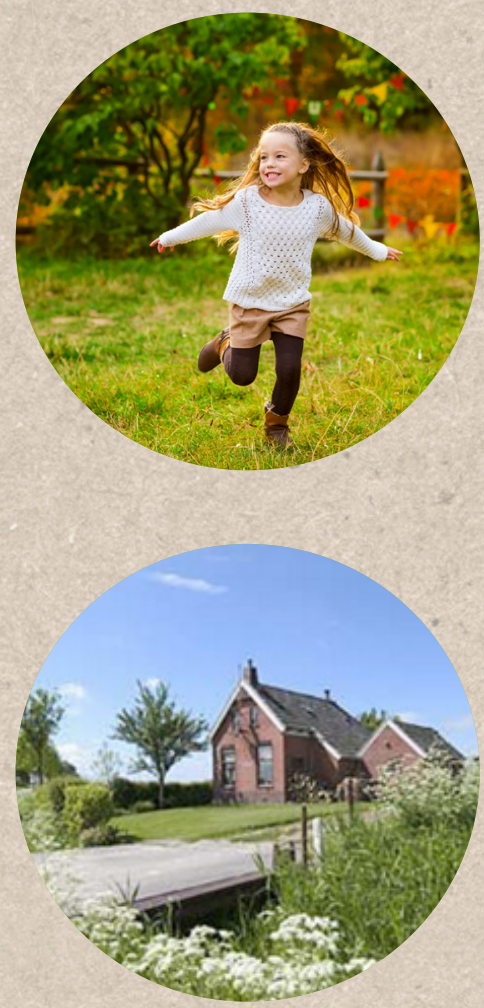

Endhoven verrasiend groen 


\section{Groene

Cirkels

\section{Wat is soortenmonitoring?}

Het meten van het effect van inrichtings- en beheersmaatregelen door bijen, zweefvliegen en vlinders systematisch te tellen.

\section{Waarom soortenmonitoren?}

- Om te kunnen laten zien wat investeringen in bij-vriendelijk beheer en inrichting hebben opgeleverd.

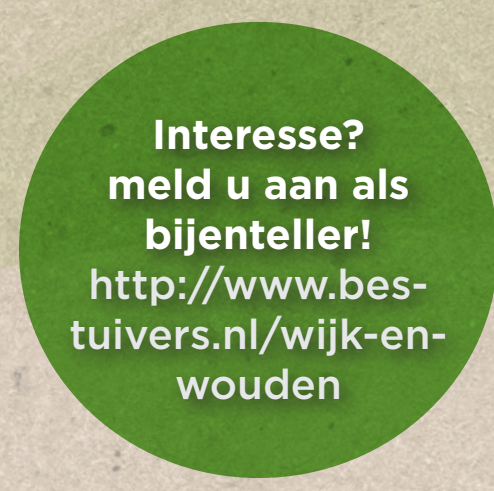

- Om inrichting en beheer te kunnen bijstellen. De aantallen en soorten die u aantreft geven informatie waar verbetermogelijkheden zitten.

\section{Belangrijk:}

- Tel aantal soorten, en aantallen per soort(groep)

- Leg de grenzen van uw telgebied goed vast

- Tel minstens twee verschillende jaren: de situatie voorafgaand aan uw maatregelen en de situatie in een (aantal) jaar erna.

- Doe minstens drie telrondes per jaar vánwege verschillen in vliegperioden:

- Ronde 1: april (bloei wilgen en sleedoorns).

- Ronde 2: mei (bloei meidoorns en fluitenkruid).

- Ronde 3: juli-augustus (bloei berenklauw en boerenwormkruid).

- Een extra ronde in juni is aan te raden omdat sommige soorten juist dan hun optimum hebben.

- Pas het tijdstip van uw telronde aan op de bloei van genoemde plantensoorten.

- Breng per telronde dezelfde hoeveelheid tijd door in terrein, ook in de verschillende jaren.

\section{Wie kan soortenmonitoren?}

Herkennen van met name bijen en zweefvliegen is moeilijk; er zijn veel soorten, die moeilijk op naam zijn te brengen.

\section{- Bijen-, zweefvlieg en vlinderexperts}

- Voordeel: Betrouwbare en complete resultaten, duiding van effecten.

- Nadeel: arbeidsintensief, draagt weinig bij aan kennis of draagvlak bij actoren.

- Vrijwilligers en niet-specialisten door: Mensen op te leiden tot bijen-, zweefvliegen- en/of vlinder-kenners.

- Monitoring te vereenvoudigen: Aantallen van beperkte set soorten (bijv. van zoekkkaart "Bijen in de tuin") of van soortgroepen tellen.

- Voordelen: geen specialisten nodig, verspreiding van enthousiasme en kennis.

- Nadelen: resultaten van mindere kwaliteit dan van specialisten.

\section{Monitoring randvoorwaarden}

Daarnaast kunt u ook de aanwezigheid van randvoorwaarden voor bijen per terrein(deel) monitoren. Dit vormt een mooie combinatie met soortmonitoring. Heineken experimenteert hiermee.

- Voordelen: geen specialisten nodig, makkelijk uitvoerbaar, sturingsinstrument om randvoorwaarden voor bijen op uw terrein in orde te krijgen.

- Nadelen: levert geen informatie over effecten of over verbetermogelijkheden van uw maatregelen in beheer en inrichting. 


\section{Groene Cirkels}

\section{INTRODUCTIE POWERPOINT-PRESENTATIE EN INFOBLADEN}

Bij deze trainingsmap met infobladen hoort een powerpoint-presentatie. Deze bevat slides waar u uit kunt putten voor de training 'Samenwerken aan het Bijenlandschap'. De doelgroep voor-deze presentatie is breed: van politici, bestuurders, managers, beleidsmedwerkers tot aannemers en hoveniers. De presentatie is zo opgezet dat u uw presentatie voor de training kunt afstemmen op de doelgroep. Zie hiervoor het infoblad 'Afstemming doelgroep en voorbeelden training', even verderop in deze map.

Wanneer $u$ een training wilt geven kunt $u$ de presentatie opvragen bij:

Sabine.vanrooij@wur.nl.

Wanneer u de presentatie wilt bekijken kan dat op de de website

https://www.groenecirkels.nl/nl/groenecirkels/Themas/Leefomgeving/Project-GroeneCirkel-Bijenlandschap.htm.

In het notitiescherm van de powerpoint-slides vindt $u$ de begeleidende tekst bij de slides.

De training "Samenwerken aan het Bijenlandschap" is bedoeld om een breed spectrum van actoren in en rond het gebied van Wijk en Wouden:

- te enthousiasmeren om mee te werken aan de realisatie van het bijenlandschap,

- te informeren over wat een bijenlandschap inhoudt,

- handelingsperspectief te geven om daadwerkelijk een bijdrage te leveren.

Ook kunt u de training gebruik om deelnemers op ideeen te brengen: wat kunnen ze doen, wie hebben ze nodig, wat hebben ze nodig, ondernemen ze iniatief?

Elk infoblad in deze trainingsmap correspondeert met een aantal slides van de powerpoint-presentatie die gegeven wordt tijdens de training. De infobladen zijn daarnaast ook afzonderlijk te begrijpen. In de powerpoint-presentatie wordt teruggegrepen op eerdere slides. Bij het weglaten van slides is het goed om te controleren of u geen informatie weglaat waar later naar wordt terugverwezen.

In de presentatie zijn interactieve blokjes opgenomen. De slides die hierbij horen zijn herkenbaar aan het hiernaast gelegen figuur. In deze blokjes kunt u uw deelnemers aan het woord kunt laten en hun inbreng vragen.

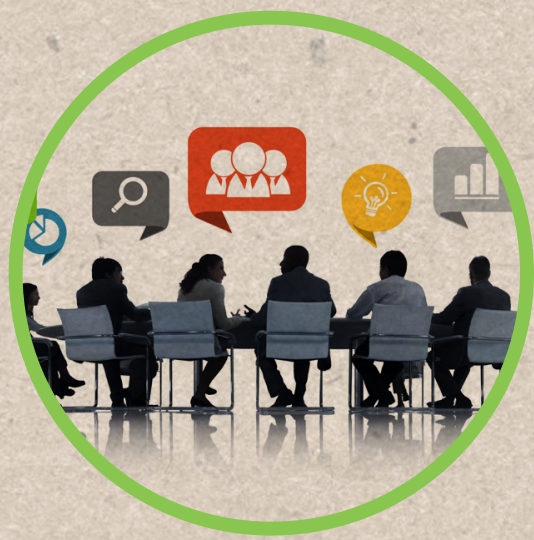




\section{Groene Cirkels}

\section{OVERZICHT POWERPOINTSLIDES EN INFOBLADEN}

Hieronder volgt een overzicht van de powerpoint-slides en de relatie tussen deze slides met de infobladen

\section{Waarom?}

Interactief blok: Wat is uw ambitie in relatie tot het bijenlandschap voor het terrein dat u (samen met anderen) beheert of waarvan u het beheer kunt beïnvloeden?

- Een bijenlandschap in land van Wijk en Wouden.

- Voor welke soorten maken we het landschap beter?

- Het landschap door de ogen van .... Bijen, Zweefvliegen en Vlinders.

\section{Wat is er nodig?}

- Bouwstenen voor het bijenlandschap. Wat is nodig voor een bijenlandschap?

- Bij-, zweefvlieg- en vlindervriendelijke inrichting.

- Bij-, zweefvlieg- en vlindervriendelijk beheer.

- Bermen.

- Bedrijventerreinen.

- Parken en openbaargroen.

- Tuinen.

- Onkruidbestrijding.

- Machinerie.

Interactief blok: Wat is uw bijgestelde ambitie, kunt u deze nu preciezer formuleren? Interactief blok: Wat is het verschil tussen de dagelijkse praktijk in de inrichting en beheer van uw terrein en de ambitie die u heeft?

\section{Waar?}

- Kansrijke plekken in Land van Wijk en Wouden en omgeving.

- Initiatieven in het gebied.

\section{Hoe krijgen we dat voor elkaar?}

- Breed draagvlak.

- Doorvoeren van de ambitie in de hele keten.

- Bestek en EMVI's.

- Toezicht.

- Overleg tussen og - aannemer.

- Financiële mogelijkheden en keuzes (kosten en baten).

- Monitoring van doelbereik.

Interactief blok: Waar zitten bij uw eigen bedrijf of bij anderen waarmee u een terrein beheert de sterke en zwakke punten in de organisatie van een bestuiversvriendelijk beheer en inrichting?

Interactief blok: Ga naar buiten en kijk waar inrichting en beheer aangepast kunnen worden

Interactief blok: Wat gaat u doen? Wat / wie heeft u nodig? 


\section{Groene Cirkels \\ AFSTEMMING DOELGROEP EN VOORBEELDEN VAN TRAININGEN}

\section{Voor hoveniers en uitvoerders}

- Gebruik secties: Waarom?, Wat is er nodig?, Hoe krijgen we dat voor elkaar? (overleg opdrachtgever-aannemer, interactie, wat gaat u doen?).

- Ga naar buiten, bekijk uw terrein, ga meteen aan de slag met de kennis.

- Laat voorbeelden zoeken voor kansen voor bijvriendelijke inrichting en beheer die uitvoerbaar zijn.

- Leg iets aan: een nestelplek.

- Haal ideeën naar boven en verzamel ze.
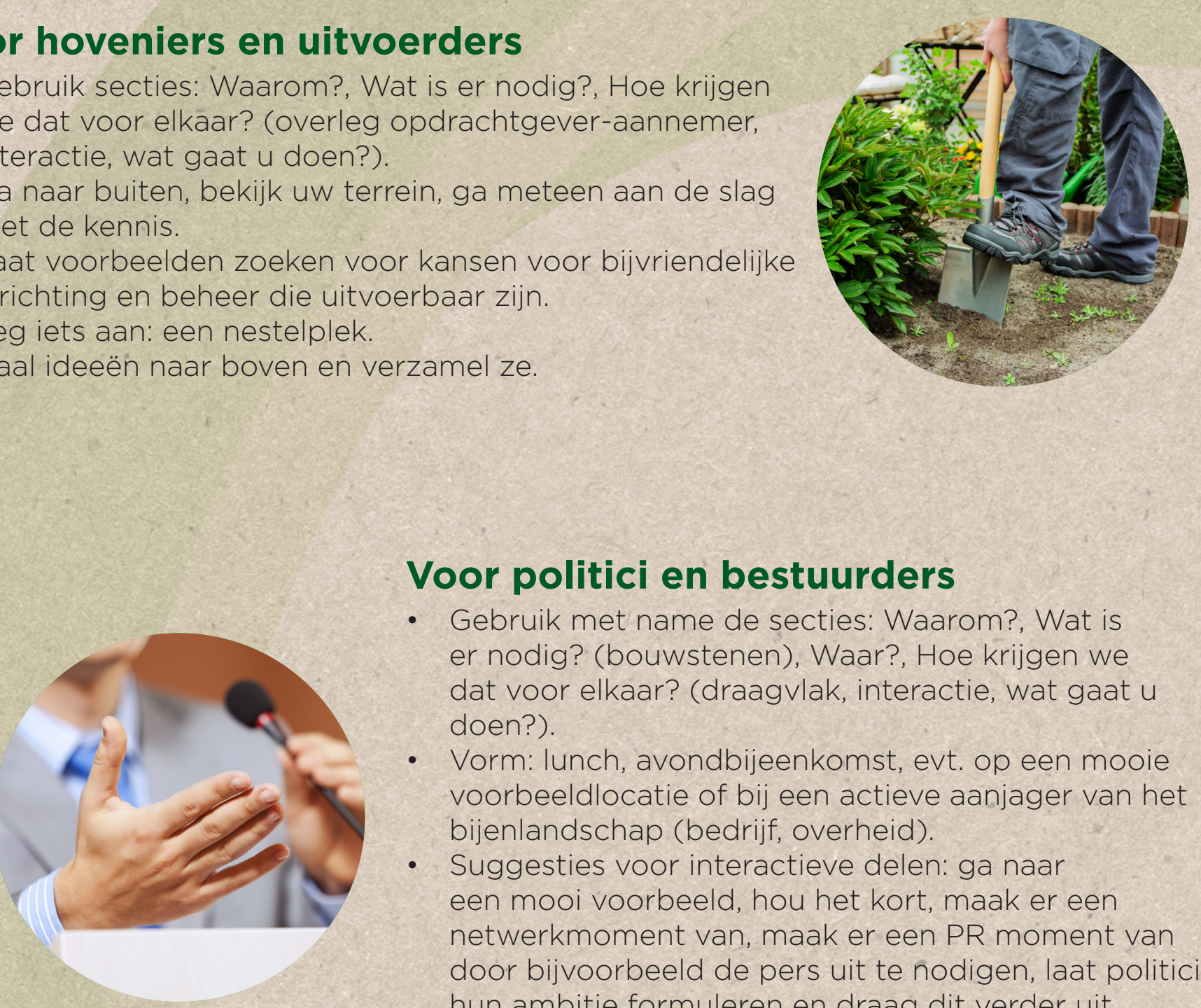

\section{Voor politici en bestuurders}

- Gebruik met name de secties: Waarom?, Wat is er nodig? (bouwstenen), Waar?, Hoe krijgen we dat voor elkaar? (draagvlak, interactie, wat gaat u doen?).

- Vorm: lunch, avondbijeenkomst, evt. op een mooie voorbeeldlocatie of bij een actieve aanjager van het bijenlandschap (bedrijf, overheid).

- Suggesties voor interactieve delen: ga naar een mooi voorbeeld, hou het kort, maak er een netwerkmoment van, maak er een PR moment van door bijvoorbeeld de pers uit te nodigen, laat politici hun ambitie formuleren en draag dit verder uit.

\section{Voor beleidsmedewerkers en aannemers}

- Gebruik met name de secties: Waarom?, Wat is er nodig? (bouwstenen), Waar?, Hoe krijgen we dat voor elkaar?

- Vorm: middag, lunch, avondbijeenkomst, evt. Op een mooie voorbeeldlocatie of bij een actieve aanjager van het bijenlandschap (bedrijf, overheid).

- Suggesties voor interactieve delen: ga naar een mooi voorbeeld, hou het kort, maak er een netwerkmoment van, haal ideeën naar boven.

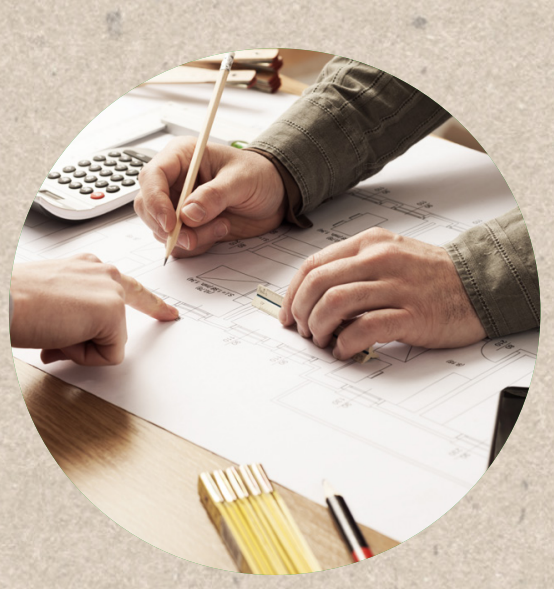




\section{Groene Cirkels}

\section{HOE KUNT U ONLINE \\ MEDIA INZETTEN?}

Door het gebruik van online media kunt $u$ meer effect hebben van uw training, en betrekt u nog meer mensen. Er zijn verschillende kanalen waar u gebruik van kunt maken.

Twitter: korte actuele nieuwsberichten verspreiden aan een groot publiek.

\#Bijenlandschap

@groenecirkels

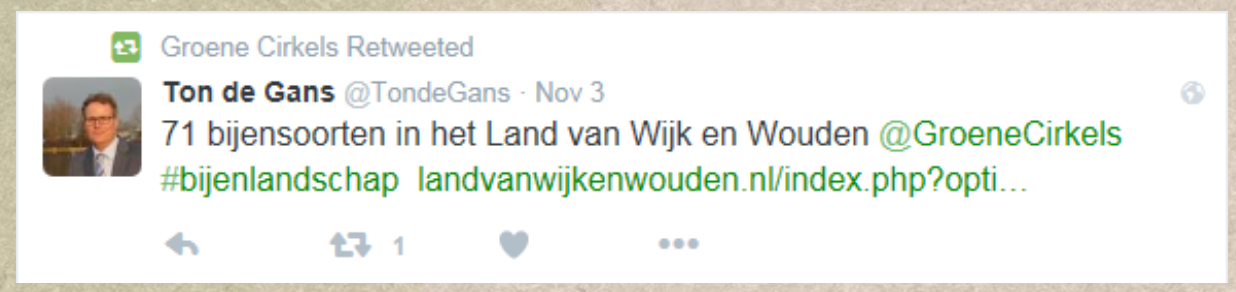

Facebook: voor het verspreiden van successen, weetjes en interessante waarnemingen onder een breed publiek. Plaats interessante berichten bijvoorbeeld op

\section{'Natuur Leiden - ZHL'. \\ 'Bijen in de buurt'}

$f$

Voor nieuwsberichten die te maken hebben met het opbouwen van het Bijenlandschap, aankondigingen van bijeenkomsten e.d. kan de website van Groene Cirkels gebruikt worden. Er is zowel een Nederlandse als een Engelse versie. www.groenecirkels.nl en www.greencircles.nl

Naast www.groenecirkels.nl maakt Groene Cirkels ook gebruik van sites van diverse bronnen. Denk hierbij aan de website van Alterra Wageningen UR, die van de provincie Zuid-Holland, die van HEINEKEN, maar ook die van andere partijen.

Kranten en nieuwssites zijn ook waardevolle middelen om nieuws te verspreiden. Stuur persberichten dus ook naar lokale media en naar Linneke van Heemskerck-Duker.

\section{Contact}

Om uw nieuwsbericht zo goed mogelijk te verspreiden kunt u contact opnemen met Linneke van Heemskerck-Duker. Zij kan u helpen met het plaatsen van uw bericht op de andere websites of social media pagina's. Ook voor vragen kunt u bij haar terecht.

Linneke van Heemskerck-Duker

E-mail: I.van.heemskerckduker@pzh.nl. 

Cirkels

\section{DEELNEMERSLIJST}

Graag dit blad opsturen naar Sabine van Rooij

(zie colofon voor contactgegevens).

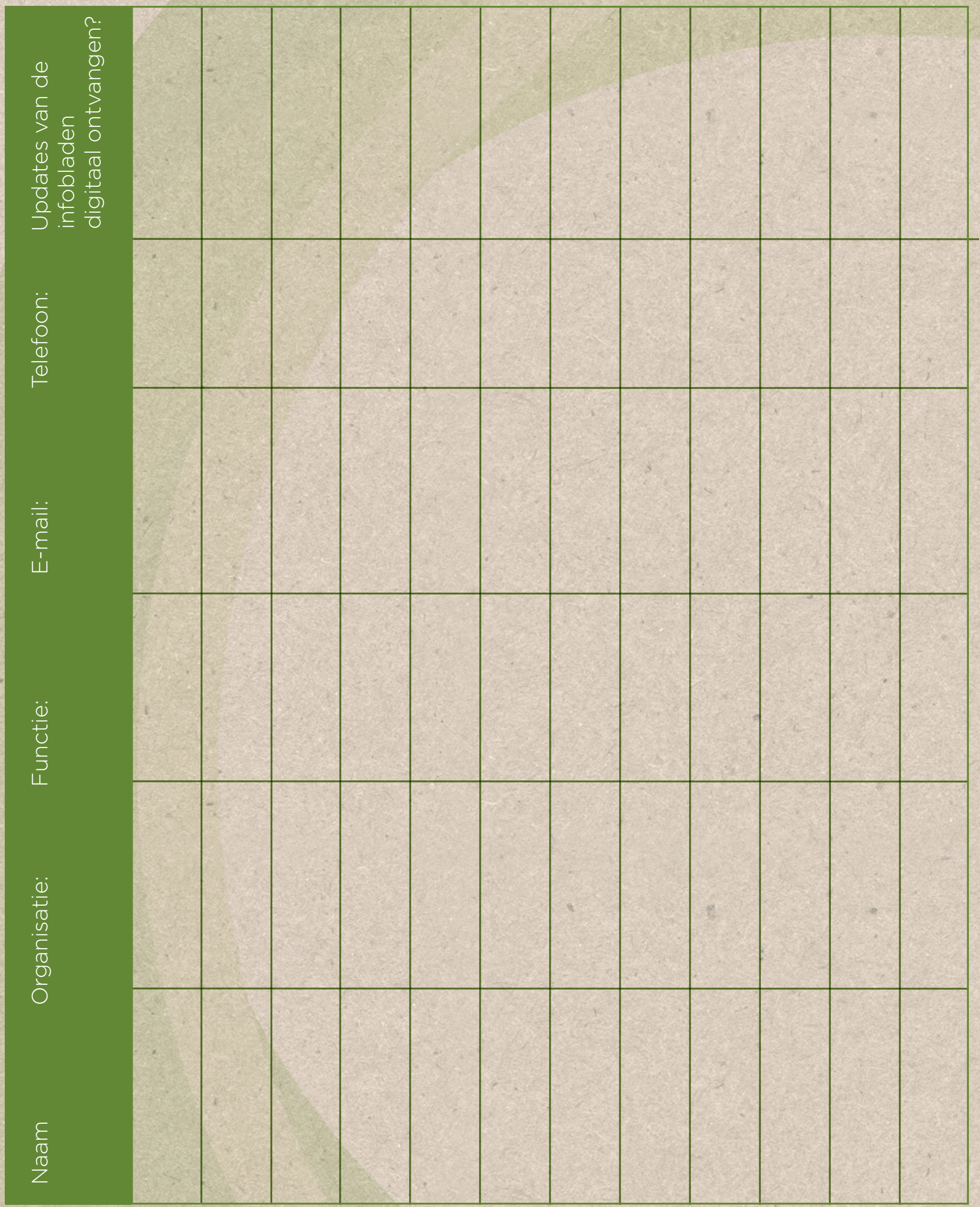

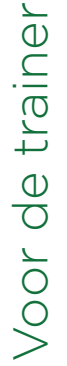




\section{Groene \\ RESULTAAT TRAINING}

Cirkels

\begin{tabular}{l|}
\hline Trainer \\
\hline Naam: \\
\hline Organisatie: \\
\hline Functie: \\
\hline E-mailadres: \\
\hline Telefoon: \\
\hline
\end{tabular}

\begin{tabular}{l}
\hline Training \\
\hline Datum: \\
\hline Locatie (adres, plaatsnaam): \\
\hline Doelgroep: \\
\hline Aantal deelnemers: \\
\hline $\begin{array}{l}\text { Deelnemerslijst aanwezig? (ja/nee) } \\
\text { Indien ja, graag deelnemerslijst meesturen }\end{array}$ \\
\hline
\end{tabular}

Resultaat

Hoe was het enthiousiasme van de deelnemers?

Is de informatie overgekomen?

Zijn de deelnemers aangezet tot handelen?

Wat zijn concrete vervolgacties van de deelnemers?

Wat waren de reacties van de deelnemers op de training?

Opmerkingen van de trainer over de training:

Boodschap aan de groene cirkel naar aanleiding van de training:

Graag dit blad opsturen naar Sabine van Rooij (zie colofon voor contactgegevens). Zij zal ervoor zorgen dat de resultaten, vragen en opmerkingen die voortkomen uit de training worden gemeld in de Groene Cirkel Bijenlandschap. Deze Groene Cirkel bestaat uit regionale actoren (overheden, bedrijven, ngo's) en kennisinstellingen die zich samen inzetten om het regionale bijenlandschap te organiseren. De Groene Cirkel Bijenlandschap komt regelmatig bijeen om initiatieven te bespreken en waar mogelijk te vertalen naar acties. 


\section{Groene

Cirkels

\section{WEBSITES}

- www.wegwijzerbestuivers.nl

- www.bijenlandschap.nl

\section{EXPERTS}

Inhoudelijk:

- Bijen, Zweefvliegen:

- Menno Reemer, EIS kenniscentrum insecten.

- menno.reemer@naturalis.nl

- Vlinders:

- Anthonie Stip, De Vlinderstichting.

- anthonie.stip@vlinderstichting.nl

- Biodiverse inrichting en beheer terreinen:

- Robbert Snep, Alterra Wageningen UR.

-robbert.snep@wur.nl

- Bouwstenen bijennetwerk en ecoprofielen:

- Sabine van Rooij, Alterra Wageningen UR.

- sabine.vanrooij@wur.nl

- (Kosten) beheer en inrichting:

- Joop Spijker, Alterra Wageningen UR.

•joop.spijker@wur.nl

Kennisuitwisseling- en overdracht:

- Netwerk betrokken partijen Bijenlandschap:

- Hannie Korthof \& Annette Piepers, St. Land van Wijk en Wouden.

-h.korthof@odwh.nl \& a.piepers@odwh.nl

- (Borging) bijvriendelijk beheer en inrichting openbaar groen:

- Hendrik Baas, Gemeente Zoetermeer.

-h.baas@zoetermeer.nl

\section{PUBLICATIES}

- Handreiking voor een Bij-zonder kleurrijk landschap 2.0

www.groenecirkèls.nl/nl/groenecirkels/Themas/Leefomgeving/Project-Groene-Cirkel-Bijenlandschap.htm - Kosten en baten bijvriendelijk beheer.

http://www.bijenlandschap.nl/wp-content/uploads/2016/06/Bijvriendelijk-beheer-brochure-10-digi.pdf

- Contouren regionaal ecologisch netwerk voor bestuivers. Groene Cirkels Bijenlandschap, stand van zaken eind 2017.

https://edepot.wur.nl/467069 


\section{Groene COLOFON}

Meegewerkt hebben:

Sabine van Rooij - Wageningen Environmental Research (projectleider)

Anouk Cormont - Wageningen Environmental Research

Nynke Lokhorst - Christelijk Hogeschool Ede

Renze van Och - Wageningen Environmental Research

Menno Reemer - EIS Kenniscentrum Insecten

Robbert Snep - Wageningen Environmental Research

Joop Spijker - Wageningen Environmental Research

Eveliene Steingröver - Wageningen Environmental Research

Anthonie Stip - De Vlinderstichting

Wim Ozinga - Wageningen Environmental Research

Arjen de Groot - Wageningen Environmental Research

Met dank aan:

Leo Adegeest - Adegeest Advies

Peter van den Akker - Zuid-Hollands Landschap

Hendrik Baas - Gemeente Zoetermeer

Marc Bel - Provincie Zuid-Holland

Erika van Drimmelen - Gemeente Zoeterwoude

Reinier Gillissen - Gemeente Zoetermeer

Lise Smits - Wageningen Universiteit

\section{Contactpersoon:}

Sabine van Rooij

Wageningen Environmental Research

Postbus 47,6700 AA Wageningen

E-mailadres: sabine.vanrooij@wur.nl

telefoonnummer: 0317-486021

Dit rapport is gratis te downloaden van https://doi.org/10.18174/520308. 


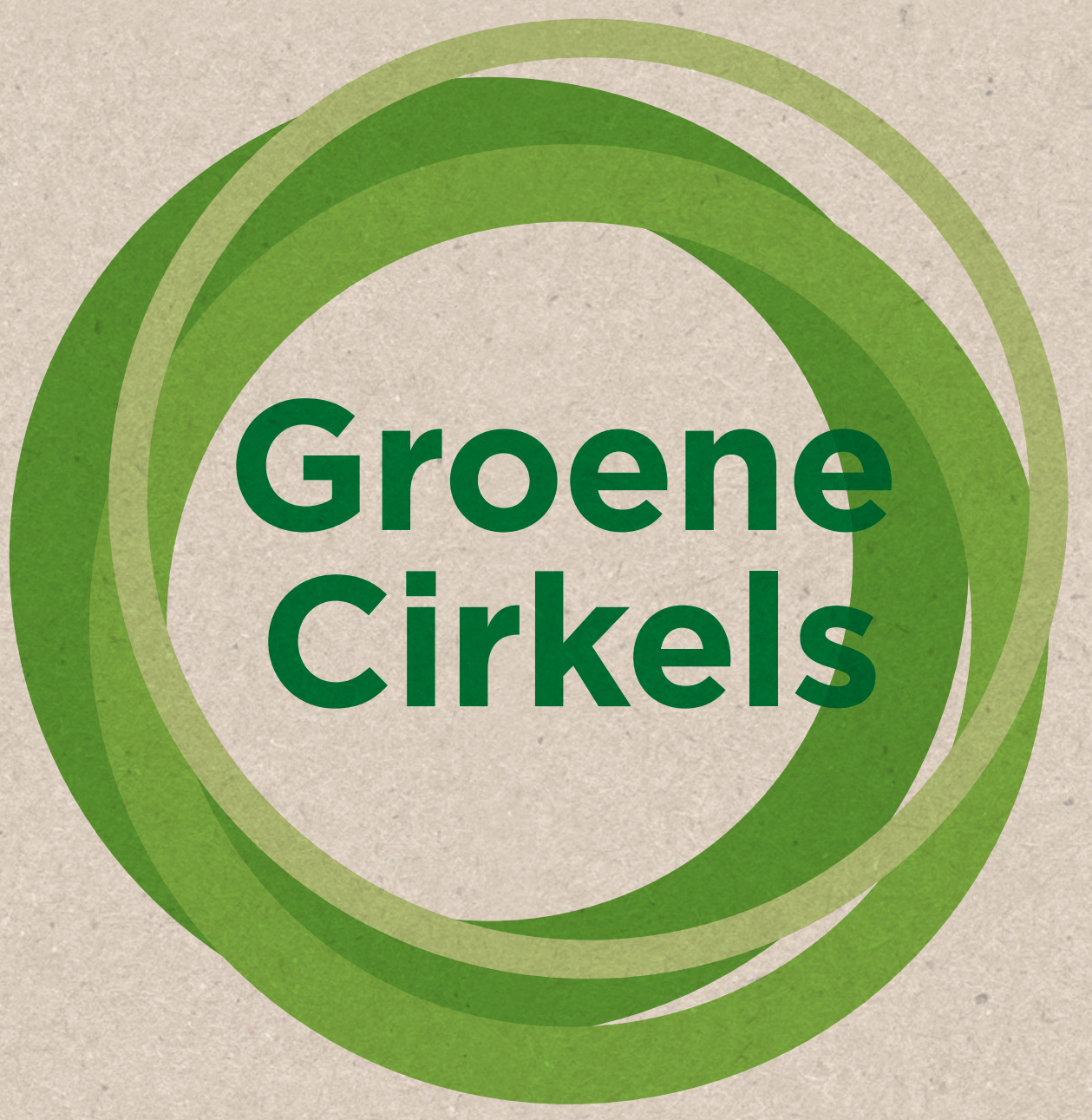

www.groenecirkels.nl

@groenecirkels 